\title{
HOW MUCH OF CHINESE EXPORTS IS REALLY MADE IN CHINA? ASSESSING DOMESTIC VALUE-ADDED WHEN PROCESSING TRADE IS PERVASIVE
}

\author{
Robert Koopman \\ Zhi Wang \\ Shang-Jin Wei \\ Working Paper 14109 \\ http://www.nber.org/papers/w14109 \\ NATIONAL BUREAU OF ECONOMIC RESEARCH \\ 1050 Massachusetts Avenue \\ Cambridge, MA 02138 \\ June 2008
}

The views expressed in this paper are those of the authors alone. They do not necessarily reflect the views of the US International Trade Commission, any of its individual Commissioners, any other organization that the authors are or have been affiliated with, nor the National Bureau of Economic Research.

NBER working papers are circulated for discussion and comment purposes. They have not been peerreviewed or been subject to the review by the NBER Board of Directors that accompanies official NBER publications.

(C) 2008 by Robert Koopman, Zhi Wang, and Shang-Jin Wei. All rights reserved. Short sections of text, not to exceed two paragraphs, may be quoted without explicit permission provided that full credit, including (C) notice, is given to the source. 
How Much of Chinese Exports is Really Made In China? Assessing Domestic Value-Added

When Processing Trade is Pervasive

Robert Koopman, Zhi Wang, and Shang-Jin Wei

NBER Working Paper No. 14109

June 2008, Revised December 2011

JEL No. F1,O1,O53

\section{ABSTRACT}

The rise of China in world trade has brought both benefits and anxiety to other economies. For many policy questions, it is crucial to know the extent of domestic value added (DVA) in exports, but the computation is more complicated when processing trade is pervasive. We propose a method for computing domestic and foreign contents that allows for processing trade. By our estimation, the share of domestic content in exports by the PRC was about $50 \%$ before China's WTO membership, and has risen to over $60 \%$ since then. There are also interesting variations across sectors. Those sectors that are likely labeled as relatively sophisticated such as electronic devices have particularly low domestic content (about $30 \%$ or less).

Robert Koopman

Research Division

Office of Economics

US International Trade Commission

500 E Street SW

Washington, DC 20436

Robert.Koopman@usitc.gov

Zhi Wang

Research Division

Office of Economics

US International Trade Commission

500 E Street SW

Washington, DC 20436

zhi.wang@usitc.gov
Shang-Jin Wei

Graduate School of Business

Columbia University

Uris Hall 619

3022 Broadway

New York, NY 10027-6902

and NBER

shangjin.wei@columbia.edu 


\section{Introduction}

"Made in China" is one of the most common labels one encounters in a shopping mall in the United States and Europe. Increasingly, many products that are supposed to be technically sophisticated and therefore likely to be associated with exports from highincome countries, such as digital cameras and computers, also carry that label. Since the most salient characteristic of the factor endowment in China is a vast supply of unskilled labor relative to either physical or human capital, is the country's actual export structure inconsistent with the predictions from the international trade theory based on its endowment? A possible resolution to the puzzle is that China is simply the last section of a long global production chain that ends up assembling components from various countries into a final product before it is exported to the US and EU market. Indeed, a MacBook computer carries a label at its back (in small type) that reads "Designed by Apple in California; Assembled in China.” This label is likely to be oversimplified already, as it reports only the head and the tail of a global production chain, but skips many other countries that supply other components that go into the product.

China is the archetype of a national economy that is well integrated into a global production chain. It imports raw material, equipment, and intermediate inputs, and then exports a big fraction of its output (on the order of 37\% of GDP in 2006) to the world market. The PRC is not the only country whose production and exports are a part of a global chain; Japan, Korea, Singapore, and Malaysia are some other examples of countries that participate actively in the international divisions of labor. However, the PRC is noteworthy due to its sheer size. In addition, its export/GDP ratio, at 35\% or higher in recent years, is extraordinarily high for a large economy, when compared with $8 \%$ for the US and $13 \%$ for India. With a reputation as a "world factory," China is a top supplier of manufacturing outsourcing for many global companies.

For many policy issues, it is important to assess the extent of domestic content in exports. For example, what is the effect of a currency appreciation on a country's exports? The answer depends crucially on the share of domestic content in the exports. Other things being equal, the lower the share of domestic content in the exports, the smaller the effect on trade volume a given exchange rate appreciation would have. As 
another example, what is the effect of trading with the PRC on US income inequality? The answer depends in part on whether the PRC simply exports products that are intensive in low-skilled labor or whether its exports are more sophisticated. Rodrik (2006) notes that the per capita income typically associated with the kind of goods bundle that the PRC exports is much higher than the country's actual income. He interprets this as evidence that the skill content of its exports is likely to be much higher than its endowment may imply. Schott (2008) documents an apparent rapid increase in the similarity between the PRC's export structure and that of high-income countries, and interprets it as evidence of a rise in the level of sophistication embedded in the country's exports. Wang and Wei (2008a) use disaggregated regional data to investigate the determinants of the rise in export sophistication. Indeed, many other observers have expressed fear that the PRC is increasingly producing and exporting sophisticated products and may be providing wage competition for mid- to high-skilled workers in the US and Europe. However, the calculations by Rodrik (2006) and Schott (2008) do not take into account the imported content in the country's exports. If the domestic content in exports from the PRC is low, especially in sectors that would have been considered sophisticated or high-skilled in the US, then imports from the PRC may still generate a large downward pressure on the wage of the low-skilled Americans after all (as pointed out by Krugman, 2008). These are important policy questions and have implications for both developing and developed countries. A good understanding of the nature and extent of global supply chains can provide important insights for economists and policy makers.

How would one assess foreign versus domestic content in a country's exports? Hummels et al. (2001) (HIY in subsequent discussion) propose a method to decompose a country's exports into domestic and foreign value added share based on a country's input-output (IO) table. They make a key assumption that the intensity in the use of imported inputs is the same between production for exports and production for domestic sales. This assumption is violated in the presence of processing exports. Processing exports are characterized by imports for exports with favorable tariff treatment: firms import parts and other intermediate materials from abroad, with tariff exemptions on the imported inputs and other tax preferences from local or central governments, and, after processing or assembling, export the finished products. The policy preferences for 
processing exports usually lead to a significant difference in the intensity of imported intermediate inputs in the production of processing exports and that in other demand sources (for domestic final sales and normal exports). Since processing exports have accounted for more than 50\% of China's exports every year at least since 1996, the HIY formula is likely to lead to a significant under-estimation of the share of foreign value added in its exports. In fact, most economies offer tariff reductions or exemptions on imported intermediate inputs used in production for exports. Ignoring processing exports is likely to lead to estimation errors, especially for economies that engage in a massive amount of tariff/tax-favored processing trade, such as the China, Mexico and Viet Nam.

In this paper, we aim to make two contributions to the literature. First, we present a formula for computing shares of foreign and domestic value added in a country's exports when processing exports are pervasive. We develop this formula because the production technology and input sourcing differs for goods produced for domestic consumption and normal exports compared to those produced under export processing regimes. The HIY formula is a special case of this general formula. Second, we apply our methodology to China using data for 1997, 2002, and 2007. We estimate that the share of foreign value added in China's manufactured exports was about 50\% during 1997 to 2002 before China's WTO membership, almost twice as high as that implied by the HIY formula, and has risen to over $60 \%$ in 2007 after 5 years of its WTO membership. There are also interesting variations across sectors. Those sectors that are likely labeled as relatively sophisticated such as computers, telecommunication equipments, and electronic devices have particularly low domestic content (about 30\% or less). By design, this is an accounting exercise, and does not intend to examine the determinants, driving forces and the consequences of changes in domestic contents in China's gross exports thoroughly. However, a solid methodology to estimate and account domestic and foreign value added in developing countries exports is the necessary first step toward a better understanding of these issues.

Besides the papers on vertical specialization in the international trade literature, this paper is also related to the I/O literature. In particular, Chen et al. (2004) and Lau et al (2007) are the first to develop a "non-competitive" type I/O model for China (i.e., one 
in which imported and domestically produced inputs are accounted for separately) and to incorporate processing exports explicitly. However, these papers do not describe a systematic way to infer separate input-output coefficients for production of processing exports versus those for other final demands. It is therefore difficult for others to replicate their estimates or apply their methodology to other countries. In addition, they use an aggregated version of China's 1995 and 2002 input-output tables, respectively, to perform their analysis, with 20 some goods producing industries. We provide a more upto-date and more disaggregated assessment of foreign and domestic values added in Chinese exports with 83 goods producing industries. Finally, they impose an assumption in estimating the import use matrix from the competitive type I/O table published by China's National Statistical Bureau: within each industry, the mix of the imported and domestic inputs is the same in capital formation, intermediate inputs, and final consumption. We relax this assumption by refining a method proposed in Dean, Fung, and Wang (2007) that combines China's processing imports statistics with United Nations Broad Economic Categories (UNBEC) classification.

The rest of the paper is organized as follows. Section 2 presents a conceptual framework for estimating shares of domestic and foreign value added in a country's exports when processing exports are pervasive. It also describes a mathematic programming procedure to systematically infer a set of I/O coefficients called for by the new formula but not typically available from a conventional $\mathrm{I} / \mathrm{O}$ table. Section 3 presents the estimation results for Chinese exports. Section 4 evaluate the accuracy of the estimation results by using an IO table with separate processing trade account complied by Mexico national statistical agency based 2003 economic census. Section 5 concludes.

\section{Conceptual Framework and Estimation Method}

\subsection{When special features of processing exports are not taken into account}

We first discuss how domestic and foreign contents in a country's exports can be computed when it does not engage in any processing trade. The discussion follows the input-output literature, and is the approach adopted (implicitly) by Hummels et al. (2001) 
and Yi (2003). Along the way, we will point out a clear connection between the domestic content concept and the concept of vertical specialization. ${ }^{2}$

When imported and domestically produced intermediate inputs are accounted separately, a value-based input-output table can be specified as follows: ${ }^{3}$

$$
\begin{gathered}
A^{D} X+Y^{D}=X \\
A^{M} X+Y^{M}=M \\
u A^{D}+u A^{M}+A_{v}=u
\end{gathered}
$$

where $A^{D}=\left[a_{i j}^{D}\right]$ is an $n_{x} n$ matrix of direct input coefficients of domestic products; $A^{M}=$ $\left[a^{M}{ }_{i j}\right]$ is an $n_{x} n$ matrix of direct inputs of imported goods; $Y^{D}$ is an $n_{x 1}$ vector of final demands for domestically produced products, including usage in gross capital formation, private and public final consumption, and gross exports; $Y^{M}$ is an $n \times 1$ vector of final demands for imported products, including usages in gross capital formation, private and public final consumption; $X$ is a $n \times 1$ vector of gross output; $M$ is a $n \times 1$ vector of imports; $A_{v}=\left[a_{j}^{v}\right]$ is a $1 \times n$ vector of each sector $j$ 's ratio of value added to gross output, and $u$ is a $1 \times n$ unity vector. Subscripts $i$ and $j$ indicate sectors, and superscripts $D$ and $M$ represent domestically produced and imported products, respectively.

Equations (1) and (2) define two horizontal balance conditions for domestically produced and imported products, respectively. A typical row $k$ in Equation (1) specifies that total domestic production of product $k$ should be equal to the sum of the sales of product $k$ to all intermediate and final users in the economy (the final sales include domestic consumption and capital formation, plus exports of product $k$ ). A typical row $h$ in Equation (2) specifies that the total imports of product $h$ should be equal to the sum of the sales of product $h$ to all users in the economy, including intermediate inputs for all sectors, plus final domestic consumption and capital formation. Equation (3) is both a vertical balance condition, and an adding-up constraint for the input-output coefficients.

\footnotetext{
${ }^{2}$ We use the terms "domestic value added” and "domestic content” interchangeably. Similarly, we use the terms "foreign value added”, "foreign content”, and "vertical specialization” to mean the same thing.

${ }^{3}$ Such a model is called a "non-competitive" model in the IO literature. HIY (2001) do not specify this system explicitly but go straight to the implied Leontief inverse while Chen et al. (2004) specify only the first two equations. A fully specified model facilitates better understanding of the connection between vertical specialization and domestic content, and a comparison with the model in the next sub-section that features processing exports.
} 
It implies that the total output $(\mathrm{X})$ in any sector $k$ has to be equal to the sum of direct value added in sector $k$, and the cost of intermediate inputs from all domestically produced and imported products.

From Equation (1) we have

$$
X=\left(I-A^{D}\right)^{-1} Y^{D}
$$

$\left(I-A^{D}\right)^{-1}$ is the well-known Leontief Inverse, a matrix of coefficients for the total domestic intermediate product requirement. Define a vector of share of domestic content, or domestic value added, in a unit of domestically produced products, $D V S=\left\{d v s_{j}\right\}$, a $1 \times n$ vector, as the additional domestic value added generated by one additional unit of final demand of domestic products $\left(\Delta Y^{D}=u^{\prime}\right)$ :

$$
D V S=\hat{A}_{v} \Delta X / \Delta Y^{D}=\hat{A}_{v}\left(I-A^{D}\right)^{-1}=A_{v}\left(I-A^{D}\right)^{-1}
$$

where $\hat{A}_{v}$ an $n_{x} n$ diagonal matrix with $a_{j}^{v}$ as its diagonal elements. Equation (5) indicates that the domestic content for an IO industry is the corresponding column sum of the coefficient matrix for total domestic intermediate goods requirement, weighted by the direct value-added coefficient of each industry. Because standard model assumes that exports and domestic sales are produced by the same technology, the share of domestic content in final demand and the share of domestic content in total exports are the same. So Equation (5) is also the formula for the share of domestic content in total exports for each industry.

Define a vector of share of foreign content (or foreign value added) in final demand for domestically produced products by $F V S=u-D V S$. By making use of Equation (3), it can be verified that

$$
F V S=u-A_{v}\left(I-A^{D}\right)^{-1}=u A^{M}\left(I-A^{D}\right)^{-1}
$$

For each industry, this is the column sum of the coefficient matrix for total intermediate import requirement. This turns out to be the same formula used to compute vertical specialization by Hummels et al. (2001). In other words, the concepts of vertical specialization and of foreign content are identical.

\footnotetext{
${ }^{4}\left(I-A^{D}\right)$ has to be full rank.
} 


\subsection{Domestic Content in Exports When Processing Trade is Prevalent}

We now turn to the case in which tariff-favored processing exports are prevalent; these exports have a different intensity in the use of imported inputs than do domestic final sales (and normal exports). Conceptually, we wish to keep track separately of the IO coefficients of the processing exports and those of domestic final sales and normal exports. For now, we ignore the fact that these IO coefficients may not be directly available, and will discuss a formal approach to estimate them in the next subsection.

The expanded I/O table with a separate account for processing exports is represented by Figure 1.

Figure 1: Input-output table with separate production account for processing trade

\begin{tabular}{|c|c|c|c|c|c|c|}
\hline & & \multicolumn{2}{|l|}{ Intermediate use } & \multirow[b]{2}{*}{$\begin{array}{l}\text { Final use } \\
(\mathrm{C}+\mathrm{I}+\mathrm{G}+\mathrm{E})\end{array}$} & \multirow[b]{2}{*}{$\begin{array}{l}\text { Gross Output or } \\
\text { Imports }\end{array}$} \\
\hline & & & $\begin{array}{l}\text { Production for } \\
\text { domestic use \& } \\
\text { normal exports }\end{array}$ & $\begin{array}{l}\text { Production of } \\
\text { processing } \\
\text { exports }\end{array}$ & & \\
\hline & & DIM & $1,2, \ldots, \mathrm{N}$ & $1,2, \ldots, \mathrm{N}$ & 1 & 1 \\
\hline \multirow[b]{2}{*}{$\begin{array}{l}\text { Domestic } \\
\text { Intermediate } \\
\text { Inputs }\end{array}$} & $\begin{array}{lr}\text { Production } & \text { for } \\
\text { domestic } & \text { use \& } \\
\text { normal } & \text { exports } \\
\text { (D) } & \\
\end{array}$ & $\begin{array}{l}1 \\
\cdot \\
\cdot \\
\mathrm{N}\end{array}$ & $Z^{D D}$ & $Z^{D P}$ & $Y^{D}-E^{P}$ & $X-E^{P}$ \\
\hline & $\begin{array}{l}\text { Processing } \\
\text { Exports (P) }\end{array}$ & $\begin{array}{l}1 \\
\cdot \\
\cdot \\
\mathrm{N}\end{array}$ & 0 & 0 & $E^{P}$ & $E^{P}$ \\
\hline \multicolumn{2}{|c|}{ Intermediate Inputs from Imports } & $\begin{array}{l}1 \\
\cdot \\
\cdot \\
\cdot \\
\mathrm{N}\end{array}$ & $Z^{M D}$ & $Z^{M P}$ & $Y^{M}$ & $M$ \\
\hline \multicolumn{2}{|l|}{ Value-added } & 1 & $V^{D}$ & $V^{P}$ & & \\
\hline \multicolumn{2}{|l|}{ Gross output } & 1 & $X-E^{P}$ & $E^{P}$ & & \\
\hline
\end{tabular}

We use superscript $P$ and $D$, respectively, to represent processing exports on one hand, and domestic sales and normal exports on the other. This expanded IO model can be formally described by the following system of equations:

$$
\begin{aligned}
& {\left[\begin{array}{cc}
I-A^{D D} & -A^{D P} \\
0 & I
\end{array}\right]\left[\begin{array}{l}
X-E^{P} \\
E^{P}
\end{array}\right]=\left[\begin{array}{l}
Y^{D}-E^{P} \\
E^{P}
\end{array}\right]} \\
& A^{M D}\left(X-E^{P}\right)+A^{M P} E^{P}+Y^{M}=M \\
& u A^{D D}+u A^{M D}+A_{v}^{D}=u
\end{aligned}
$$




$$
u A^{D P}+u A^{M P}+A_{v}^{P}=u
$$

This is a generalization of the model discussed in the previous subsection. Equations (7) and (8) are a generalization of Equations (1)-(2), and Equations (9)-(10) are a generalization of Equation (3), with a separate account for processing exports. Equations (9) and (10) are also the new adding-up constraint for the IO coefficients.

The analytical solution of the system is

$$
\left[\begin{array}{l}
X-E^{P} \\
E^{P}
\end{array}\right]=\left[\begin{array}{cc}
I-A^{D D} & -A^{D P} \\
0 & I
\end{array}\right]^{-1}\left[\begin{array}{l}
Y^{D}-E^{P} \\
E^{P}
\end{array}\right]
$$

The generalized Leontief inverse for this expanded model can be computed as follows:

$$
B=\left[\begin{array}{cc}
I-A^{D D} & -A^{D P} \\
0 & I
\end{array}\right]^{-1}=\left[\begin{array}{ll}
B^{D D} & B^{D P} \\
B^{P D} & B^{P P}
\end{array}\right]=\left[\begin{array}{cc}
\left(I-A^{D D}\right)^{-1} & \left(I-A^{D D}\right)^{-1} A^{D P} \\
0 & I
\end{array}\right]
$$

Substituting Equation (12) into Equation (11), we have:

$$
X-E^{P}=\left(I-A^{D D}\right)^{-1}\left(Y^{D}-E^{P}\right)+\left(1-A^{D D}\right)^{-1} A^{D P} E^{p}
$$

Substituting Equation (13) into Equation (8), the total demand for imported intermediate inputs is

$$
M-Y^{M}=A^{M D}\left(I-A^{D D}\right)^{-1}\left(Y^{D}-E^{P}\right)+A^{M D}\left(1-A^{D D}\right)^{-1} A^{D P} E^{P}+A^{M P} E^{p}
$$

It has three components: the first term is total imported content in final domestic sale and normal exports, and the second and the third terms are indirect and direct imported content in processing exports, respectively.

We can compute vertical specialization (VS) or foreign content share in processing and normal exports in each industry separately:

$$
\left|\begin{array}{c}
V S S^{D} \\
V S S^{P}
\end{array}\right|^{T}=\left|\begin{array}{c}
u A^{M D}\left(I-A^{D D}\right)^{-1} \\
u A^{M D}\left(1-A^{D D}\right)^{-1} A^{D P}+u A^{M P}
\end{array}\right|^{T}
$$

The total foreign content share in a particular industry is the sum of the two weighted by the share of processing and non-processing exports $s^{p}$ and $u-s^{p}$, where both $s$ and $u$ are a 1 by n vector:

$$
\overline{V S S}=\left(u-s^{P}, s^{P}\right)\left|\begin{array}{l}
V S S^{D} \\
V S S^{P}
\end{array}\right|
$$

The foreign content (or foreign value-added) share in a country's total exports is: 


$$
\operatorname{TVSS}=u A^{M D}\left(I-A^{D D}\right)^{-1} \frac{E-E^{P}}{t e}+u\left(A^{M D}\left(1-A^{D D}\right)^{-1} A^{D P}+A^{M P}\right) \frac{E^{P}}{t e}
$$

where te is a scalar, the country's total exports. Equation (16) is a generalization of Equation (7), the formula to compute industry-level share of vertical specialization. Equation (17) is a generalization of the formula for country-level share of vertical specialization proposed by Hummels et al. (2001, page 80). In particular, either when $A^{D D}=A^{D P}$ and $A^{M D}=A^{M P}$, or when $E^{P} /$ te $=0$, Equation (18) reduces to the HIY formula for VS.

Similarly, the domestic content share for processing and normal exports at the industry level can be computed separately:

$$
\begin{aligned}
\left|\begin{array}{cc}
D V S^{D} \\
D V S^{P}
\end{array}\right|^{T} & =\bar{A}_{v} B=\left(\begin{array}{ll}
A_{v}^{D} & \left.A_{v}^{p}\right)
\end{array}\left[\begin{array}{cc}
\left(I-A^{D D}\right)^{-1} & \left(I-A^{D D}\right)^{-1} A^{D P} \\
0 & I
\end{array}\right]\right. \\
& =\left|\begin{array}{c}
A_{v}^{D}\left(I-A^{D D}\right)^{-1} \\
A_{v}^{D}\left(I-A^{D D}\right)^{-1} A^{D P}+A_{v}^{P}
\end{array}\right|^{T}
\end{aligned}
$$

The total domestic content share in a particular industry is a weighted sum of the two:

$$
\overline{D V S}=\left(u-s^{P}, s^{P}\right)\left|\begin{array}{l}
D V S^{D} \\
D V S^{P}
\end{array}\right|
$$

The domestic content share in a country’s total exports is:

$$
T D V S=A_{V}^{D}\left(I-A^{D D}\right)^{-1} \frac{E-E^{P}}{t e}+\left(A_{V}^{D}\left(1-A^{D D}\right)^{-1} A^{D P}+A_{V}^{P}\right) \frac{E^{P}}{t e}
$$

Either when $A^{D D}=A^{D P}$ and $A_{v}^{D}=A_{v}^{P}$, or when $E^{P} / t e=0$, Equation (20) reduces to the HIY formula in Equation (5). Note we can easily verify that for both processing and normal exports, the sum of domestic and foreign content shares is unity.

\section{$\underline{2.3 \text { Estimation Issues }}$}

Equations (18-20) allows us to compute the shares of domestic content in processing and normal exports for each industry as well as in a country's total exports. However, statistical agencies typically only report a traditional I/O matrix, $A^{D}$, and sometimes $A^{M}$, but not $A^{D P}, A^{D D}, A^{M P}$ and $A^{M D}$ separately. Therefore, a method to estimate these matrices, based on available information, has to be developed. In this sub-section, 
we propose to do this via a quadratic programming model by combining information from trade statistics and conventional I/O tables.

The basic idea of this model is to use information from the standard I/O table to determine sector-level total imports/exports, and information from trade statistics to determine the relative proportion of processing and normal exports within each sector, thus use up all available data to split the national economy into processing and nonprocessing blocks, each with its own IO structure. Using the data from the I/O table to determine sector-level total imports/exports helps to ensure that the balance conditions in the official I/O account are always satisfied, and that the I/O table with separate processing and non-processing accounts estimated from the model always sums to the published official table. Such a method is a formalization of the calibration methods widely used in macroeconomics and CGE modeling when the number of endogenous variables larger than the number of equations.

The following data are observable from a standard I/O table:

$x_{i}=$ Gross output of sector $i$;

$z_{i j}=$ Goods $i$ used as intermediate inputs in sector $j$;

$v_{j}=$ Value-added in sector $j$;

$m_{i}=$ Total imports of sector $i$ goods; and

$y_{i}=$ Total final demand except for exports of goods $i$.

- We combine those observed data from the $\mathrm{I} / \mathrm{O}$ table and processing trade shares ${ }^{5}$ observed from trade statistics to determine the values for:

$m_{i}^{p}=$ Imports of sector $i$ good used as intermediate inputs to produce processing exports;

$m_{i}^{d}=$ Imports of sector $i$ goods used as intermediate inputs for domestic production and normal exports;

$e_{i}^{n}=$ Normal exports of sector $i$; and

$e_{i}^{p}=$ Processing exports of sector $i$.

The partition of imports into intermediate and final use is based on a combination of China custom import statistics and UN BEC classification, as described in Dean, Fang

\footnotetext{
${ }^{5}$ Processing trade are defined by China Customs, which include trade regime "Process \& assembling "(14) and "Process with imported materials" (15) in China Customs statistics. These statistics are relatively accurate because they involve duty exemption and value-added tax rebates which under intensive Customs monitoring.
} 
and Wang (2011). The results of such partition and the actual numbers used in our empirical estimation are reported and discussed in the data source subsection later. Parameters on domestic and imported final demand can be inferred from the observed data discussed above:

$y_{i}^{m}=$ Final demand of goods $i$ from imports (residuals of $m_{i}-m_{i}^{p}-m_{i}^{d}$ );

$y_{i}^{d}=$ Final demand of goods $i$ provided by domestic production (residual of $y_{i}$ $\left.y_{i}^{m}\right)$.

All those data based on official statistics are entered our estimation model as constants.

Define $z_{i j}^{d d}=$ Domestically produced intermediate good $i$ used by sector $j$ for domestic sales and normal exports; $z_{i j}^{d p}=$ Domestically produced intermediate good $i$ used by sector $j$ for processing exports; $z_{i j}^{m d}=$ Imported intermediate good $i$ used by sector $j$ for domestic sales and normal exports; $z_{i j}^{m p}=$ Imported intermediate good $i$ used by sector $j$ for processing exports $; v_{j}^{d}=$ Direct value added by domestic and normal export production in industry $j ; v_{j}^{p}=$ Direct value added by processing export production in industry $j$. Then the IO coefficients for the expanded IO model can be written as:

$$
\begin{aligned}
& A^{D D}=\left[a_{i j}^{d d}\right]=\left[\frac{Z_{i j}^{d d}}{x_{j}-e_{j}^{p}}\right], A^{M D}=\left[a_{i j}^{m d}\right]=\left[\frac{z_{i j}^{m d}}{x_{j}-e_{j}^{p}}\right], A_{v}^{D}=\left[a_{j}^{v d}\right]=\left[\frac{v_{j}^{d}}{x_{j}-e_{j}^{p}}\right], \\
& A^{D P}=\left[a_{i j}^{d p}\right]=\left[\frac{Z_{i j}^{d p}}{e_{j}^{p}}\right], A^{M P}=\left[a_{i j}^{m p}\right]=\left[\frac{Z_{i j}^{m p}}{e_{j}^{p}}\right], A_{v}^{P}=\left[a_{j}^{v p}\right]=\left[\frac{v_{j}^{p}}{e_{j}^{p}}\right],
\end{aligned}
$$

To obtain these unobservable IO coefficients, we need estimate within-industry transactions $\left[\mathrm{z}_{\mathrm{ij}}{ }^{\mathrm{dd}}\right],\left[\mathrm{z}_{\mathrm{ij}}{ }^{\mathrm{dp}}\right],\left[\mathrm{z}_{\mathrm{ij}}{ }^{\mathrm{md}}\right]$, and $\left[\mathrm{z}_{\mathrm{ij}}{ }^{\mathrm{mp}}\right]$, as well as sector-level value added $\left[\mathrm{v}_{\mathrm{j}}{ }^{\mathrm{d}}\right]$, and $\left[\mathrm{v}_{\mathrm{j}}^{\mathrm{P}}\right]$, subject flowing $\mathrm{I} / \mathrm{O}$ account identities and statistical adding up constraints:

$$
\begin{gathered}
\sum_{j=1}^{K}\left(z_{i j}^{d d}+z_{i j}^{d p}\right)=x_{i}-e_{i}^{p}-e_{i}^{n}-y_{i}^{d} \\
\sum_{j=1}^{K}\left(z_{i j}^{m d}+z_{i j}^{m p}\right)=m_{i}-y_{i}^{m}
\end{gathered}
$$




$$
\begin{aligned}
& \sum_{j=1}^{K}\left(z_{i j}^{d d}+z_{i j}^{m d}\right)+v_{j}^{d}=x_{j}-e_{j}^{p} \\
& \sum_{i=1}^{K}\left(z_{i j}^{d p}+z_{i j}^{m p}\right)+v_{j}^{p}=e_{j}^{p} \\
& \sum_{j=1}^{K} z_{i j}^{m d}=m_{i}^{d} \\
& \sum_{j=1}^{K} z_{i j}^{m p}=m_{i}^{p} \\
& \sum_{j=1}^{K}\left(z_{i j}^{d d}+z_{i j}^{d p}\right)=\sum_{j=1}^{K} z_{i j}-\left(m_{i}^{d}+m_{i}^{p}\right) \\
& Z_{i j}^{d d}+z_{i j}^{d p}+z_{i j}^{m d}+z_{i j}^{m p}=Z_{i j} \\
& v_{j}^{d}+v_{j}^{p}=v_{j}
\end{aligned}
$$

The economic meanings of these 9 groups of constraints are straightforward. Equations (21) and (22) are row sum identities for the expanded I/O account. They state that total gross output of sector $i$ has to equal to the sum of domestic intermediaries, final demand and exports (both processing and normal exports) in that sector. Similarly, total imports have to equal imported intermediate inputs plus imports delivered to final users. Equations (23) and (24) are column sum identities for the expanded I/O account. They define the value of processing exports in sector $j$ as the sum of domestic and imported intermediate inputs as well as primary factors used in producing processing exports; these four groups of constraints correspond to equations (7)-(10) in the extended I/O model respectively. Equations (25) to (29) are a set of adding up constraints to ensure that the solution from the model is consistent with official statistics on sector-level trade and within-industry transactions. Suppose there are $K$ sectors, then there will be $4 K^{2}+2 K$ unknowns and only $7 \mathrm{~K}+\mathrm{K}^{2}$ independent constraints, so we have to cast the calibration problem as a constrained optimization procedure to minimize following objective functions: 


$$
\begin{aligned}
& \operatorname{Min} S=\sum_{i=1}^{K} \sum_{j=1}^{K} \frac{\left(z_{i j}^{d d}-z 0_{i j}^{d d}\right)^{2}}{z 0_{i j}^{d d}}+\sum_{i=1}^{K} \sum_{j=1}^{K} \frac{\left(z_{i j}^{d p}-z 0_{i j}^{d p}\right)^{2}}{z 0_{i j}^{d p}}+\sum_{i=1}^{K} \sum_{j=1}^{K} \frac{\left(z_{i j}^{m d}-z 0_{i j}^{m d}\right)^{2}}{z_{i j}^{m d}} \\
& +\sum_{i=1}^{K} \sum_{i=1}^{K} \frac{\left(z_{i j}^{m p}-z 0_{i j}^{m p}\right)^{2}}{z 0_{i j}^{m p}}+\sum_{j=1}^{K} \frac{\left(v_{j}^{d}-v 0_{j}^{d}\right)^{2}}{v 0_{j}^{d}}+\sum_{j=1}^{K} \frac{\left(v_{j}^{p}-v 0_{j}^{p}\right)^{2}}{v 0_{j}^{p}}
\end{aligned}
$$

Where z's and $v$ 's are variables to be estimated, those variables with a 0 in the suffix denote initial values.

These initial values are guesses about the values of variables based on official statistics using proportional assumptions (will discuss below). However, because all parameters in the 9 groups of linear constraints (right hand side of equations (21) to (29)) were directly or indirectly obtained from observable official statistical sources, model solutions thus are restricted into a convex set and will be relatively stable respect to variations in these initial values as long as all the parameters in these linear constraints kept as constants.

The initial value of $\mathrm{z}_{\mathrm{ij}}{ }^{\mathrm{md}}$ and $\mathrm{z}_{\mathrm{ij}}{ }^{\mathrm{md}}$, are generated by allocating $m_{i}^{d}$ and $m_{i}^{p}$ in proportion to input i's usage in sector $\mathrm{j}$ as equation (31):

$$
z 0_{i j}^{m p}=\frac{z_{i j}\left(e_{j}^{p} / x_{j}\right)}{\sum_{k}^{N} z_{i k}\left(e_{k}^{p} / x_{k}\right)} m_{i}^{p} \quad z 0_{i j}^{m d}=\frac{z_{i j}\left(x_{j}-e_{j}^{p}\right) / x_{j}}{\sum_{k}^{N} z_{i k}\left(x_{k}-e_{k}^{p}\right) / x_{k}} m_{i}^{d}
$$

The split of total inter-sector intermediate inputs flow from sector i to sector $j$ between normal and processing use are based on their proportion in gross output. The residuals of the total intermediate inputs and the imported intermediate inputs estimated from equation (31) are taken the initial values for domestically produced intermediate inputs as equations (32) and (33):

$$
\begin{aligned}
& z 0_{i j}^{d d}=z_{i j} \frac{\left(x_{j}-e_{j}^{p}\right)}{x_{j}}-z 0_{i j}^{m d} \\
& z 0_{i j}^{d p}=z_{i j} \frac{e_{j}^{p}}{x_{j}}-z 0_{i j}^{m p}
\end{aligned}
$$

The initial values for direct value added in the production for processing exports in sector $j\left(v 0_{j}^{p}\right)$, are generally set to be the residuals implied by Equation (24). However, we set a minimum value at the sum of labor compensation and depreciation in 
a sector multiplied by the share of processing exports in that sector's total output. In other words, the initial value $v 0_{j}^{p}$ is set to equal the greater of the residuals from Equation (24) or the minimum value. The initial value for direct value added in the production for domestic sales and normal exports $\left(v 0_{j}^{d}\right)$ is set as the difference between $v_{j}$ (from the I/O table) and $v 0_{j}^{p}$.

We conduct some sensitivity checks using alternative initial values to empirically verify whether the model solutions are sensitive to these initial values. It turns out that these alternative initial values do not materially alter our basic conclusions. We implement this quadratic programming model in GAMS (Brooke et al, 2005), related computer programs and data files will be available at the USITC website for downloading.

\section{Estimation Results}

After describing the data sources, we report and discuss the estimation results for shares of domestic and foreign content in Chinese exports at the aggregate level, and by sector, firm ownership and major destination countries.

\subsection{Data}

Inter-industry transaction and (direct) value-added data are from China’s 1997, 2002 and 2007 benchmark I/O tables published by the National Bureau of Statistics of China (NBS). We use detailed exports and imports data of 1997, 2002, and 2007 from the General Customs Administration of China to help differentiate the processing and normal trade in each sector. The trade statistics are first aggregated from the 8-digit HS level to China's I/O industries, and then used to compute the share of processing exports in each I/O industry. Modifying a method from Dean, Fung and Wang (2009), we partition all imports in a given commodity classification into three parts based on the distinction between processing and normal imports in the trade statistics, and on the UN BEC classification scheme: (a) intermediate inputs in producing processing exports; (b) intermediate inputs for normal exports and other domestic final sales; and (c) those used in gross capital formation and final consumption. A summary of these trade statistics as a percentage of China's total imports along with share of processing exports during 1996- 
2008 is reported in Table 1, which shows a downward trend for the use of imported inputs in producing processing exports, and an upward trend in their use in producing normal trade and domestic final sales. Processing exports as a share of China's total merchandise exports also gradually decline in recent years. Such trend seems partially reflects the consequence of a series of policy measures to change the preferences to processing trade and foreign invested enterprises has adopted by Chinese government since the end of 2006.

Detailed trade share parameters for each I/O industry in the three benchmark year (1997, 2002, and 2007) are listed in Appendix tables A-C. These data computed directly from detailed Chinese official trade statistics are important to understand our estimates of domestic and imported content in Chinese gross exports, especially their change trends over time.

\section{(Inset Table 1 here)}

\section{$\underline{\text { 3.2 Domestic and foreign contents in total exports }}$}

Table 2 presents the results for the decomposition of aggregate foreign and domestic value-added shares in 1997, 2002 and 2007. For comparison, the results from the HIY method that ignores processing trade are also reported. The estimated aggregate domestic value added share in China's merchandise exports was 54\% in 1997, and 60.6\% in 2007. For manufacturing products, these estimated shares are slightly lower in levels but trending upward significantly at 50\% in 1997 and 59.7\% in 2007, respectively. In general, the estimated direct domestic value-added shares are less than half of the total domestic value-added shares. However, the estimated indirect foreign value-added share was relatively small; most of the foreign content comes from directly imported foreign inputs, especially in 1997 and 2002. The indirect foreign value-added increase over time, and reach about a quarter of China's directly imported foreign inputs in 2007, indicating the share of simple processing and assembling of foreign parts is declining, while more imported intermediates are being used in the production of other intermediate inputs that are then used in the production process.

(Insert table 2 here) 
Relative to the estimates from the HIY method, our procedure produces estimates of a much higher share of foreign value added in Chinese gross exports and with a different trend over time. To be more precise, estimates from the HIY method show that the foreign content share (total VS share) increased steadily from 17.6\% in 1997 to 28.7\% in 2007 for all merchandise exports, and from $19.0 \%$ to $27.1 \%$ for manufacturing only during the same period. In contrast, our estimates suggest a trend in the opposite direction, with the share of foreign value added in all merchandise exports falling from $46 \%$ in 1997 to $39.4 \%$ in 2007 , and a similar decline for the share in manufacturing exports, it fell from 50\% in 1997 to $40.3 \%$ in 2007. The decline occur mainly during 2002-2007 period, which corresponds to the first 5 years of China's entry to the WTO. Our estimates indicate that the HIY method appears to incorrectly estimate both the level and the trend in domestic versus foreign content in the PRC's exports.

What accounts for the difference between ours and HIY approaches? There are at least three factors drive the change of foreign content of the country's gross exports: (1) the relative proportions of its total imports used as intermediate inputs in producing processing exports and domestic sales \& normal exports; (2) the share of processing exports in its total exports; and (3) the sector composition of its exports. Because processing exports tend to use substantially more imported inputs, and processing exports account for a major share of China's total exports, the HIY indicator is likely to substantially underestimate the true for foreign content in China's exports. This explains the level of domestic content by our measure is much lower than that of the HIY indicator. On the other hand, as exporting firms (both those producing for normal exports and those for processing exports) gradually increase their intermediate inputs sourcing from firms within China or multinationals move their upstream production to be near their downstream production, the extent of domestic content in exports rose over time. This exactly is what has happened since China joining the WTO. However, because exports from industries with relatively lower domestic content often grow faster due to dramatic inflow of foreign direct investment, the composition of a countries total exports may play as an offsetting factor to reduce the share of domestic value-added in the country's gross exports thus slow down the increase of domestic value-added share in a country’s total exports. As Chinese government start to reduce the policy incentives for 
both Foreign Invested Enterprises (FIE) and processing exports at the end of 2006, we are observing a trend of increasing domestic contents in Chinese exports as China continue its industrial upgrading in the years to come.

Our interpretation is confirmed by DVA shares for processing and normal exports estimated separately (Table 3). There is a more than 10 percentage point increase in the total foreign value-added share for domestic sales and normal exports between 1997 and 2007, which is consistent with the trend indicated by HIY measure. However, in processing exports we see that more domestic-produced inputs were used, domestic value-added share increased from $20.7 \%$ in 1997 to $37.0 \%$ in 2007 , up more than 16 percentage point. Because processing exports still constitute more than $50 \%$ of China's total exports in 2007, which resulting the weighted average total domestic value-added share went up during the decades.

There are conflicting forces at work. On the one hand, as domestic input suppliers increase their quality over time, and multinationals move more and more of their upstream production into China, exporting firms may decide to increase local sourcing of their inputs. On the other hand, the reductions in the country's trade barriers also encourage exporting firms to use more imported inputs. These two opposing forces partially offset each other. However, on net, the domestic content share in China's exports appears to be on the rise. Looking ahead, the share of imported content in exports could fall or rise, depending on the relative speed with which domestic input suppliers and multi-nationals can step up their quality and variety versus the extent of additional reductions in the cost of using imported inputs.

\section{(insert table 3 here)}

We perform a number of robustness checks on the sensitivity of our main results to alternative ways of setting the initial values of the variables and the share parameters of import use. First, we initialize $v 0_{j}^{p}$ and $v 0_{j}^{d}$ by apportioning the observed direct value added in a sector to processing exports and other final demands based on their respective portions in the sector's total output. Second, we initialize $v 0_{j}^{p}$ either at the residuals implied by equation (24) if the residuals are positive, or by following the previous alternative if the residuals are non-positive. Third, when we partition imports into 
different users, we use the average of a three-year period (previous, current, and following years) rather than just one year's statistics. Fourth, we experiment with $0 \%$ versus $10 \%$ annual depreciation rate for capital goods. These variations produce relatively little change in the main results. For example, the estimated share of domestic value added in manufacturing exports lies in a relatively narrow range between ?\% and ?\% in 2002, and between ?\% and ?\% in 2007.

\subsection{Domestic content in exports by firm ownership}

Since foreign-invested firms account for over half of China's exports, compare the share of domestic content in exports between them and other Chinese firms may help us better to understand why there is a raising trend of domestic value-added share in China's total exports. However, there is no information on separate input-output coefficients by firm ownership, our estimation assumes that they are the same on this dimension. The variation in the share of domestic content comes from different degrees of reliance on processing exports with a sector, and differences in the sector composition of their total exports.

Estimates of the domestic content shares by firm ownership are presented in Table 4. The results show that exports by wholly foreign owned enterprises exhibit the lowest share of domestic valued-added (at 33.4\% in 2002 and increase to 44.1\% in 2007), followed by Sino-foreign joint venture companies (about 44\% in both 2002 and 2007). Exports from Chinese private enterprises embodied the highest domestic content shares (83.9\% and 80.8\% in 2002 and 2007, respectively), while those from the state-owned firms were in the middle (about $70 \%$ in both years). Note that these estimates represent the best guesses based on currently available information; better estimates can be derived once information on I/O coefficients by firm ownership becomes available.

The most noticeable feature of this table is the raising domestic contents in export produced by foreign invested firms, their DVA share increased more than 10 percentage points between 2002 to 2007(There is a 10.5\% percentage point increase for wholly Foreign Owned firms, and a 13.6 percentage point increase for joint ventures), while DVA share of Chinese domestic firms basically stay steady during the same period. This indicates the raise of domestic contents in Chinese exports during the first 5 years of 
China in WTO is mainly due to FIE sourcing more of their intermediate inputs within China. This is consistent with the observation of more and more multinationals move their upstream production to China getting closer to their downstream production already in China and FIE using more and more intermediate inputs from local suppliers.

Further exam the change of domestic value-added share across firms with the same ownership but engage in processing and non-processing exports reveals that firms engage in normal exports and domestic sales used more imported intermediate inputs while firms engage in processing exports sourced more of their intermediate inputs domestically, regardless their ownership types. Therefore, we can conclude that the raise of domestic value-added content share in Chinese exports are majorly caused by China's processing exports using more locally supplied intermediate inputs in 2007 than that in $2002^{6}$. If this trend continues, the difference in the intensity of using imported inputs for processing and non-processing exports will be further reduced in next decades.

\section{(Insert table 4 here)}

\subsection{Domestic content by sector}

To see if there are interesting patterns at the sector level that helps to explain the decline trend of imported contents in China's total exports, and further assess whether the increasing domestic value-added share reflect actual upgrade of Chinese industrial structure, Tables 5 and 6 report, in ascending order on domestic content share, the valueadded decomposition in China manufacturing exports by industry in 2002 and 2007 respectively, together with shares of processing and foreign invested enterprises exports in each sector's exports as well as the sector's share in China's total merchandise exports. We choose to report the results from 2002 and 2007 not only because we would like use the latest I/O table released but also due to these two benchmark tables are consistently classified on most recent Chinese industry classifications, which simplifies issues involved in overtime comparison. Similar results for 1997 are omitted to save space.

Among the 57 manufacturing industries in the table, 15 have a share of domestic value-added in their exports less than 50 percent in 2002, and collectively account for

\footnotetext{
${ }^{6}$ Domestic value-added is a concept consistent with Gross Domestic products, which measures the value creation production activities occurring with national boarder regardless firm ownerships.
} 
nearly 35 percent of China's merchandise exports that year. Many low-DVA industries are likely to be labeled as relatively sophisticated, such as telecommunication equipment, electronic computer, measuring instruments, and electronic devices. A common feature of these industries is that processing exports account for over two-thirds of their exports and foreign invested enterprises played an overwhelming role. In 2007, the number of industry with less than 50 percent domestic contents in their exports declined into 10, but their exports count for more than 32 percent of China's total merchandise exports and these low-DVA industry are more concentrated in high-tech sectors. There are 11 industries in the top 15 low-DVA industries in 2002 still remain in the15 top low-DVA industries in 2007.

\section{(insert table 5 and table 6 here)}

The next 18 industries in table 6 have their share of domestic value-added in the range of 51 to 65 percent; they collectively accounted for 28 percent of China's total merchandise exports in 2002. Several labor-intensive sectors are in this group, such as furniture, toys and sports products, Leather, fur, down and related products.

The remaining 24 industries have relatively high shares of domestic value-added. However, they as a group produced only less than 30 percent of China's total merchandise exports in 2002. Apparel, the country's largest labor intensive exporting industry, which by itself was responsible for 7 percent of the country's total merchandise exports in 2002, is at the top of this group with a share of domestic content at 66 percent. The 12 industries at the bottom of Table 6 with DVA share more than 75 percent collectively produced only less 10 percent of China's total merchandise exports in 2002.

The weights of high-DVA industries in China's exports increased significantly in 2007. There are, the number of industries with DVA share more than 75 percent increase to 25 in 2007 (bottom of Table 7), and their exports constitute more than 30 percent of China's total merchandise exports in 2007. Among these High-DVA industries, we not only see the traditional labor industries such as furniture, textiles and apparel still play an significant role (account for more than half of these high DVA-sector exports), but also the increasing role of heavy and capital intensive industries such as automobile, industrial machinery and rolling steel (account for nearly one thirds of these high-DVA sector's 
exports). The data clearly indicate China's industrial upgrade is real and FIEs have played very important role in this process.

\subsection{DVA shares in Chinese exports by trading partners}

By assuming domestic and foreign value added shares in per unit gross exports are the same for all destination countries in each IO industry and export regime, we can further estimate the domestic value-added share in China's exports to each of its major trading partners. The decomposition results for China's total merchandise exports to each of its major trading partners are reported in Table 7 in increasing order of the estimated domestic value-added share. Note, however, the variation by destination in this method is caused solely by China's export structure to each of its trading partners (exports to each individual country/region vary by sector and trade regime structures), not the direct input intensities of imported intermediates in producing such exports.

Hong Kong, the United States, Singapore, Taiwan and Malaysia are at the top of the table in both 2002 and 2007, with less than or about 50/60 percent of China's domestic value-added embodied in its exports to these five destinations in 2002 and 2007 respectively. Since a large portion of Chinese exports to Hong Kong are re-exports to the United States, the U.S. remain as China's largest exports market in both 2002 and 2007. The lower domestic value-added share in its exports to the U.S. may partially explain why Chinese exports continued their rapid expansion in the U.S. market despite RMB gradually appreciation since July 2005. China's exports to the U.S. have started to slow down since 2008 when China return to peg exchange its rate to U.S. dollars because the world financial crisis, likely because of other macro economic factors and policy measures adopted by the Chinese government during last year. ${ }^{7}$

(Insert table 7 here)

Another interesting feature in Table 8 is that China's exports to developing countries embody much higher domestic valued added than its exports to OECD countries, but exports with higher domestic value-added (more than two thirds of the gross value of its exports) constituted of less than 13 percent of its total exports of goods

\footnotetext{
${ }^{7}$ China has taken a series of policy measures to change its preferences to processing trade and foreign invested enterprises since the end of 2006.
} 
in 2002, this share raised to about 20 percent in 2007. It is also interesting to note that the domestic value-added share in China's exports to high income country was increased between 2002 and 2007, while they are declined for exports to developing countries (split at the row of Mexico in the middle of table 8) indicating relatively more local supplied inputs were used to making exports to high income countries while relative more imported inputs were used in producing exports to developing countries.

\section{The accuracy of Content Share Estimates}

As we discussed earlier, the estimation procedure presented in this paper is a formalization and extension of calibration methods widely used in macroeconomics and CGE modeling. Different from econometric model, evaluation on the accuracy of the calibration largely rely on a benchmark data set from the real world. However, it is not very easy to find such a benchmark data set to assess the accuracy of results from our estimation method because the "true" IO account that separately trace processing exports and other production transactions in national economy is rarely exist. Fortunately, Mexico's statistical agency, the Instituto Nacional de Estadística, Geografía e Informática (INEGI), has complied 2003 benchmark IO table based on economic census, which have separate accounts for Mexico domestic and Maquiladora industries ${ }^{8}$, which is the major exports promotion program in Mexico. The table includes national production of goods and services classified under Mexico's 2002 3- and 4-digit NAICS, inputs purchased in the domestic and Maquiladora industries, and imports from the rest of the world by both economies. The domestic and foreign content share computed directly from this special Mexico IO table provides a reference benchmark to test the performance of the estimation method we proposed. Based on exports and import statistics for Maquiladora industries in the World Trade Atlas and Mexico's aggregate 2003 IO table, we implemented the same quadratic programming model that generates domestic/foreign content estimates for Chinese exports, to compute domestic and foreign value-added share in Mexico manufacturing exports, and report the estimation results in Table 8. The three panels in table 8 lists direct/total domestic/foreign value-added share for normal, processing and total exports respectively. To quantitatively assess know how much each set of value-added share estimates differs from the "true" share data computed directly from the Mexico IO table with

\footnotetext{
${ }^{8}$ We are grateful to INEGI for providing us with the input-output table.
} 
a separate processing trade account, we report three type metrics in the three bottom row of table 8 .

The first bottom row list the absolute difference between the estimated share and the "true" shares computed directly from Mexico IO table with a separate processing trade account for manufacture as a whole. The errors for various share estimates seems less than 3 percentage point. However, it is the proportionate errors and not the absolute errors that matter; therefore, we computed the "Mean Absolute Percentage Error" with respect to the true shares as follows:

$$
M A P E=\frac{100 \bullet \sum_{i=1}^{n}\left|s_{i}-s 0_{i}\right|}{\sum_{i=1}^{n} s 0_{i}}
$$

where $\mathrm{s}_{\mathrm{i}}$ is the estimated share and $\mathrm{s}_{\mathrm{i}}$ share is the reference share for industry $\mathrm{i}$. The resulted index number is reported in the second bottom row. The error range from $4 \%$ to $17 \%$ for normal exports, $14 \%$ to $28 \%$ for processing exports and $12 \%$ to $15 \%$ for total exports. Numbers in the last row of table 8 are the correlation coefficients between the estimated share and the reference shares, they reveal that our estimates are highly correlated with the true shares computed directly from Mexico IO table with a separate processing trade account for normal and total exports, while the correlation are lower for processing exports.

\section{Concluding Remarks}

Segmentation of production across countries allows for reductions in production costs and more efficient allocation of resources. The opening-up of China has likely facilitated this process. A quantitative assessment of the extent of its participation in global production chains allows us to get a better grasp of many policy questions, including the effect of an exchange rate change on bilateral trade balances.

In this paper, we first present a general framework in assessing the shares of domestic and foreign value added in a country's exports when tariff-favored processing exports are pervasive. This formula nests the existing best known approach (HIY, 2001) as a special case. Because some of the $\mathrm{I} / \mathrm{O}$ coefficients called for by the new formula are not readily available from conventional I/O tables, we propose an easy-to-replicate mathematical programming procedure to estimate these coefficients by combining information from detailed trade statistics (which records processing and normal 
exports/imports separately) with conventional input-output tables. This methodology should be applicable to Vietnam, Mexico, and many other developing countries that engage in a significant amount of processing exports.

By applying our methodology to Chinese data We find several interesting patterns. First, the share of foreign content in manufacturing exports from China was close to $50 \%$ during 1997-2002, almost twice as high as that calculated using the HIY formula. Second, the share of domestic content increased from 51\% in 2002 to $60 \%$ in 2007, which corresponds to the first five years of China's membership in the WTO. We also report interesting heterogeneity across sectors: those sectors that are likely to be labeled as sophisticated or high-skilled, such as computers, electronic devices, and telecommunication equipment, tend to have notably low shares of domestic content. Conversely, many sectors that are relatively intensive in low-skilled labor, such as apparel, are likely to exhibit a high share of domestic content in the country's exports. Finally, we find that foreign invested firms (including both wholly-owned foreign firms and Sino-foreign joint venture firms) tend to have a relatively low share of domestic content in their exports.

There are several areas in which future research can improve upon the estimation in this paper. First, we assign initial values of the direct domestic value added for processing exports at the industry level based on the information in a conventional I/O table. If a firm-level survey data becomes available that tracks the direct value added for processing and normal exports separately, we can improve the accuracy of our estimates. Second, as an inherent limitation of an I/O table, the input-output coefficients are assumed to be fixed - that's the nature of a Leontief technology - rather than be allowed to respond to price changes. This could be problematic when a big change in export volume, such as what China has been experiencing, induces a change in the world market price for imported inputs, which in turn could trigger a change in the underlying production technology and in the corresponding I/O coefficients. These could be fruitful areas for future research. 
Table 1: Major trade share parameters used in estimation, 1997-2008

\begin{tabular}{|c|c|c|c|c|c|c|}
\hline \multirow{2}{*}{ Year } & \multicolumn{2}{|c|}{ Imported intermediates \% } & \multicolumn{2}{|c|}{ Imported capital goods \% } & \multirow{2}{*}{$\begin{array}{c}\text { Imported final } \\
\text { Consumption } \\
\%\end{array}$} & \multirow{2}{*}{$\begin{array}{c}\text { Processing } \\
\text { exports as \% } \\
\text { of total } \\
\text { exports }\end{array}$} \\
\hline & $\begin{array}{l}\text { for processing } \\
\text { exports }\end{array}$ & for normal use & $\begin{array}{l}\text { for processing } \\
\text { exports }\end{array}$ & $\begin{array}{l}\text { for normal } \\
\text { use }\end{array}$ & & \\
\hline & (1) & (2) & (3) & (4) & (5) & (6) \\
\hline 1996 & 46.2 & 26.8 & 16.7 & 8.1 & 2.2 & 56.0 \\
\hline 1997 & 51.2 & 28.2 & 12.1 & 7.3 & 1.3 & 55.1 \\
\hline 1998 & 50.7 & 28.2 & 9.7 & 10.0 & 1.4 & 57.4 \\
\hline 1999 & 43.6 & 35.0 & 8.2 & 11.2 & 2.0 & 57.3 \\
\hline 2000 & 39.4 & 41.2 & 8.5 & 9.1 & 1.8 & 55.7 \\
\hline 2001 & 36.6 & 41.2 & 8.7 & 11.6 & 1.9 & 55.9 \\
\hline 2002 & 38.0 & 39.1 & 10.2 & 11.0 & 1.8 & 55.9 \\
\hline 2003 & 35.0 & 41.8 & 10.7 & 10.8 & 1.6 & 56.0 \\
\hline 2004 & 34.7 & 43.0 & 11.8 & 8.9 & 1.5 & 56.3 \\
\hline 2005 & 36.1 & 43.6 & 10.6 & 8.1 & 1.5 & 55.6 \\
\hline 2006 & 35.3 & 44.2 & 9.8 & 8.9 & 1.7 & 53.6 \\
\hline 2007 & 32.7 & 47.3 & 9.0 & 7.6 & 3.3 & 50.1 \\
\hline 2008 & 27.5 & 53.5 & 8.1 & 7.2 & 3.7 & 48.1 \\
\hline
\end{tabular}

Source: Authors' calculations based on official China Custom trade statistics and the United Nation Broad Economic Categories (UNBEC) classification scheme.

Note: "Normal use" refers to "normal exports and domestic sales." The UNBEC scheme classifies each HS 6-digit product into one of three categories: "intermediate inputs," "capital goods," and "final consumption." For the first two categories, we further decompose the imports into two subcategories: "processing imports" by customs declaration are classified as used for producing processing exports and cannot be sold to any domestic users by regulation, and the remaining imports are classified as for normal use. Capital goods are part of the final demand in a conventional I/O model (Column (1) to (5) sum to 100\%). However, this classification may under-estimate the import content of exports. We therefore also experiment with classifying a fraction of the capital goods as inputs used in current year of production. This is discussed in Section 3.2. 
Table 2 Shares of domestic and foreign value added in total exports (\%)

\begin{tabular}{lcccccr}
\hline & \multicolumn{3}{c}{ The HIY Method } & \multicolumn{3}{c}{ The KWW Method } \\
\hline & $\mathbf{1 9 9 7}$ & $\mathbf{2 0 0 2}$ & $\mathbf{2 0 0 7}$ & $\mathbf{1 9 9 7}$ & $\mathbf{2 0 0 2}$ & $\mathbf{2 0 0 7}$ \\
All Merchandise & & & & & & \\
Total Foreign value-added & 17.6 & 25.1 & 28.7 & 46.0 & 46.1 & 39.4 \\
$\quad$ Direct foreign value-added & 8.9 & 14.7 & 13.7 & 44.4 & 42.5 & 31.6 \\
Total Domestic Value-added & 82.4 & 74.9 & 71.3 & 54.0 & 53.9 & 60.6 \\
$\quad$ Direct domestic value-added & 29.4 & 26.0 & 20.3 & 22.2 & 19.7 & 17.1 \\
& & & & & & \\
Manufacturing Goods Only & & & & & & \\
Total Foreign value-added & 19.0 & 26.4 & 27.1 & 50.0 & 48.7 & 40.3 \\
$\quad$ Direct foreign value-added & 9.7 & 15.6 & 16.3 & 48.3 & 45.1 & 32.4 \\
Total Domestic Value-added & 81.1 & 73.6 & 72.9 & 50.0 & 51.3 & 59.7 \\
$\quad$ Direct domestic value-added & 27.5 & 24.6 & 24.6 & 19.6 & 18.1 & 16.5 \\
\hline
\end{tabular}

Source: Authors' estimates based on China's 1997, 2002 and 2007 Benchmark input-output table published by Bureau of National Statistics and Official China trade statistics from China Customs.

Note: The HIY method refers to estimates from using the approach in Hummels, Ishii, and Yi (2001). The KWW method refers to estimates from using the approach developed in this paper that takes into account special features of processing exports. 
Table 3: Domestic and Foreign Values Added: Processing vs. Normal Exports

(in percent of total exports)

\begin{tabular}{lrrrrrr}
\hline & \multicolumn{3}{c}{ Normal Exports } & \multicolumn{3}{c}{ Processing Exports } \\
\hline & $\mathbf{1 9 9 7}$ & $\mathbf{2 0 0 2}$ & $\mathbf{2 0 0 7}$ & $\mathbf{1 9 9 7}$ & $\mathbf{2 0 0 2}$ & $\mathbf{2 0 0 7}$ \\
All Merchandise & & & & & & \\
Total Foreign value-added & 5.2 & 10.4 & 16.0 & 79.0 & 74.6 & 62.7 \\
$\quad$ Direct foreign value-added & 2.0 & 4.2 & 5.0 & 78.6 & 73.0 & 58.0 \\
Total Domestic Value-added & 94.8 & 89.6 & 84.0 & 21.0 & 25.4 & 37.3 \\
$\quad$ Direct domestic value-added & 35.1 & 31.9 & 23.4 & 11.7 & 10.1 & 10.9 \\
& & & & & & \\
Manufacturing Goods Only & & & & & & \\
Total Foreign value-added & 5.5 & 11.0 & 16.4 & 79.4 & 75.2 & 63.0 \\
$\quad$ Direct foreign value-added & 2.1 & 4.5 & 5.2 & 79.0 & 73.6 & 58.3 \\
Total Domestic Value-added & 94.5 & 89.0 & 83.6 & 20.7 & 24.8 & 37.0 \\
$\quad$ Direct domestic value-added & 31.5 & 29.5 & 22.4 & 11.7 & 10.0 & 10.9 \\
\hline
\end{tabular}

Source: Authors' estimates based on China's 1997, 2002 and 2007 Benchmark input-output table published by Bureau of National Statistics and Official China trade statistics from China Customs.

Note: The HIY method refers to estimates from using the approach in Hummels, Ishii, and Yi (2001). The KWW method refers to estimates from using the approach developed in this paper that takes into account special features of processing exports. 
Table 4: Shares of Domestic Value Added in Exports by Firm Ownership (\%), 2002 and 2007

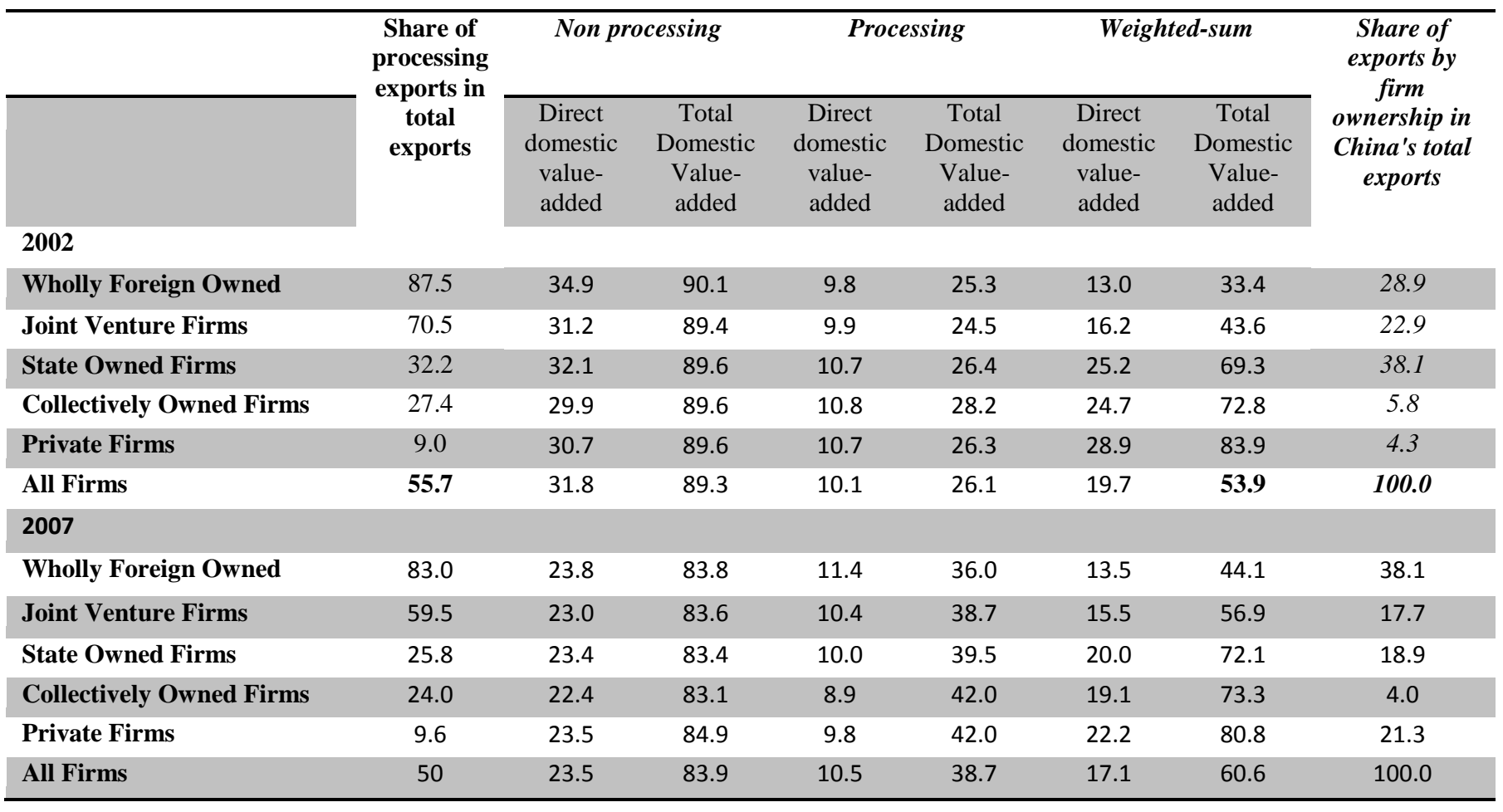

Source: Source: Authors' estimates based on China's 2002 and 2007 Benchmark input-output table published by Bureau of National Statistics and Official China trade statistics from China Customs. Input/output structure is assumed to be the same for a given export regime within a sector across all type firms. The variation of domestic value-added by firm types is due solely to variation in sector composition and the relative reliance on processing exports. 
Table 5 Domestic Value-added Share in Manufacturing Exports by Sector, 2002

\begin{tabular}{|c|c|c|c|c|c|c|c|c|c|}
\hline \multirow{3}{*}{ IO Industry description } & \multicolumn{6}{|c|}{ Value-added decomposition \% } & \multirow{3}{*}{$\begin{array}{c}\% \text { of } \\
\text { processing } \\
\text { exports }\end{array}$} & \multirow{3}{*}{$\begin{array}{c}\text { \% of } \\
\text { FIE } \\
\text { exports }\end{array}$} & \multirow{3}{*}{$\begin{array}{c}\% \text { of } \\
\text { merchandise } \\
\text { exports }\end{array}$} \\
\hline & \multicolumn{2}{|c|}{$\begin{array}{c}\text { Non- } \\
\text { processing }\end{array}$} & \multicolumn{2}{|c|}{ Processing } & \multicolumn{2}{|c|}{$\begin{array}{l}\text { Weighted } \\
\text { sum }\end{array}$} & & & \\
\hline & FVA & DVA & FVA & DVA & FVA & DVA & & & \\
\hline Ship building & 17.7 & 82.3 & 85.3 & 14.7 & 82.5 & 17.5 & 95.8 & 21.0 & 0.6 \\
\hline Electronic computer & 16.4 & 83.6 & 81.3 & 18.7 & 80.7 & 19.3 & 99.1 & 89.7 & 7.0 \\
\hline Household Audiovisual Apparatus & 17.5 & 82.5 & 78.7 & 21.3 & 73.0 & 27.0 & 90.6 & 62.3 & 5.2 \\
\hline Printing, Reproduction of Recording Media & 8.9 & 91.1 & 80.3 & 19.7 & 68.1 & 31.9 & 83.0 & 62.7 & 0.3 \\
\hline Plastic & 15.6 & 84.4 & 89.7 & 10.3 & 63.4 & 36.6 & 64.5 & 51.2 & 2.4 \\
\hline Electronic Component & 15.4 & 84.6 & 67.2 & 32.8 & 61.9 & 38.1 & 89.7 & 87.5 & 3.4 \\
\hline Steelmaking & 11.0 & 89.0 & 87.2 & 12.8 & 55.8 & 44.3 & 58.8 & 86.1 & 0.0 \\
\hline Nonferrous metal pressing & 13.8 & 86.2 & 92.5 & 7.5 & 50.7 & 49.3 & 46.9 & 48.7 & 0.4 \\
\hline Measuring Instruments & 14.2 & 85.8 & 67.1 & 32.9 & 50.5 & 49.5 & 68.6 & 51.8 & 1.8 \\
\hline Paper and Paper Products & 9.2 & 90.8 & 87.6 & 12.4 & 48.9 & 51.1 & 50.7 & 57.0 & 0.5 \\
\hline Furniture & 11.7 & 88.3 & 87.5 & 12.5 & 47.5 & 52.5 & 47.2 & 56.8 & 1.7 \\
\hline $\begin{array}{l}\text { Articles for Culture, Education and Sports } \\
\text { Activities }\end{array}$ & 12.5 & 87.5 & 61.8 & 38.2 & 47.3 & 52.7 & 70.6 & 56.3 & 3.3 \\
\hline Nonferrous metal smelting & 11.1 & 88.9 & 89.4 & 10.6 & 46.4 & 53.6 & 45.0 & 17.4 & 0.8 \\
\hline Smelting of Ferroalloy & 16.5 & 83.6 & 87.1 & 13.0 & 45.2 & 54.8 & 40.8 & 13.1 & 0.2 \\
\hline Synthetic Materials & 19.5 & 80.5 & 62.9 & 37.1 & 44.8 & 55.2 & 58.3 & 65.4 & 0.3 \\
\hline Petroleum refine and Nuclear Fuel & 20.6 & 79.4 & 94.5 & 5.5 & 44.3 & 55.7 & 32.1 & 24.9 & 0.8 \\
\hline Motor vehicles & 10.5 & 89.6 & 90.0 & 10.0 & 38.4 & 61.6 & 35.2 & 48.2 & 0.8 \\
\hline Glass and Its Products & 13.2 & 86.8 & 83.5 & 16.5 & 36.4 & 63.6 & 33.0 & 48.8 & 0.5 \\
\hline Leather, fur, down and related products & 8.1 & 91.9 & 59.7 & 40.4 & 36.1 & 63.9 & 54.3 & 50.3 & 4.5 \\
\hline Chemical Products for Daily Use & 14.7 & 85.3 & 73.2 & 26.8 & 36.0 & 64.1 & 36.3 & 43.6 & 0.4 \\
\hline Wearing apparel & 8.7 & 91.3 & 65.7 & 34.3 & 34.4 & 65.6 & 45.1 & 39.2 & 7.0 \\
\hline Chemical Fiber & 19.8 & 80.2 & 90.8 & 9.2 & 34.3 & 65.7 & 20.5 & 29.2 & 0.0 \\
\hline Other special industrial equipment & 10.8 & 89.3 & 68.0 & 32.0 & 33.6 & 66.4 & 39.9 & 44.0 & 1.3 \\
\hline Boiler, engines and turbine & 14.1 & 85.9 & 86.9 & 13.1 & 33.5 & 66.5 & 26.7 & 28.4 & 0.4 \\
\hline Other industrial machinery & 9.9 & 90.1 & 61.4 & 38.6 & 32.4 & 67.6 & 43.7 & 43.7 & 3.5 \\
\hline Iron-smelting & 13.2 & 86.8 & 89.0 & 11.0 & 31.2 & 68.8 & 23.7 & 3.0 & 0.1 \\
\hline Railroad transport equipment & 16.2 & 83.9 & 85.4 & 14.6 & 29.9 & 70.1 & 19.9 & 5.9 & 0.1 \\
\hline Wood, Bamboo, Rattan, Palm and Straw Products & 12.2 & 87.8 & 88.7 & 11.3 & 27.2 & 72.8 & 19.6 & 45.6 & 1.0 \\
\hline Knitted and crocheted fabrics and articles & 9.4 & 90.6 & 65.3 & 34.7 & 27.1 & 72.9 & 31.6 & 34.2 & 5.8 \\
\hline $\begin{array}{l}\text { Agriculture, forestry, animal husbandry and fishing } \\
\text { machinery }\end{array}$ & 14.3 & 85.7 & 86.1 & 13.9 & 27.1 & 72.9 & 17.8 & 20.8 & 0.1 \\
\hline Pesticides & 23.0 & 77.0 & 88.5 & 11.5 & 27.1 & 72.9 & 6.3 & 14.4 & 0.2 \\
\hline
\end{tabular}




\begin{tabular}{|c|c|c|c|c|c|c|c|c|c|}
\hline Hemp textiles & 10.5 & 89.5 & 88.3 & 11.7 & 25.7 & 74.3 & 19.5 & 19.5 & 0.3 \\
\hline Textiles productions & 9.9 & 90.1 & 71.1 & 28.9 & 24.6 & 75.5 & 24.0 & 31.8 & 1.4 \\
\hline Cotton textiles & 8.2 & 91.8 & 64.5 & 35.6 & 24.3 & 75.7 & 28.7 & 28.8 & 3.3 \\
\hline Fire-resistant Materials & 9.5 & 90.5 & 84.6 & 15.4 & 23.8 & 76.2 & 19.1 & 49.8 & 0.1 \\
\hline Metalworking machinery & 12.8 & 87.2 & 81.2 & 18.8 & 21.9 & 78.1 & 13.3 & 27.0 & 0.2 \\
\hline Medicines & 9.8 & 90.2 & 75.7 & 24.3 & 20.9 & 79.1 & 16.9 & 28.7 & 0.7 \\
\hline Pottery and Porcelain & 11.8 & 88.2 & 85.3 & 14.8 & 20.2 & 79.8 & 11.4 & 33.1 & 0.7 \\
\hline Fertilizers & 15.6 & 84.4 & 90.3 & 9.7 & 18.9 & 81.1 & 4.5 & 21.7 & 0.1 \\
\hline Basic Chemical Raw Materials & 12.9 & 87.1 & 56.3 & 43.7 & 18.0 & 82.0 & 11.7 & 18.8 & 2.0 \\
\hline Rolling of Steel & 9.8 & 90.2 & 59.5 & 40.5 & 17.7 & 82.3 & 16.0 & 16.8 & 0.3 \\
\hline Cement, Lime and Plaster & 9.0 & 91.0 & 79.8 & 20.3 & 14.0 & 86.0 & 7.0 & 77.7 & 0.1 \\
\hline Coking & 8.6 & 91.4 & 86.8 & 13.2 & 10.6 & 89.4 & 2.6 & 5.3 & 0.3 \\
\hline
\end{tabular}

Data source: Authors' estimates. China 2002 and 2007 benchmark IO table have 84 and 90 goods producing sector respectively, they both concord to China's 4 digit classification of economic activities (GB/T 4754-2002). This concordance enable us aggregate both year's estimates to 77 consistent goods producing industries reported in this table. 
Table 6 Domestic Value-added Share in Manufacturing Exports by Sector, 2007

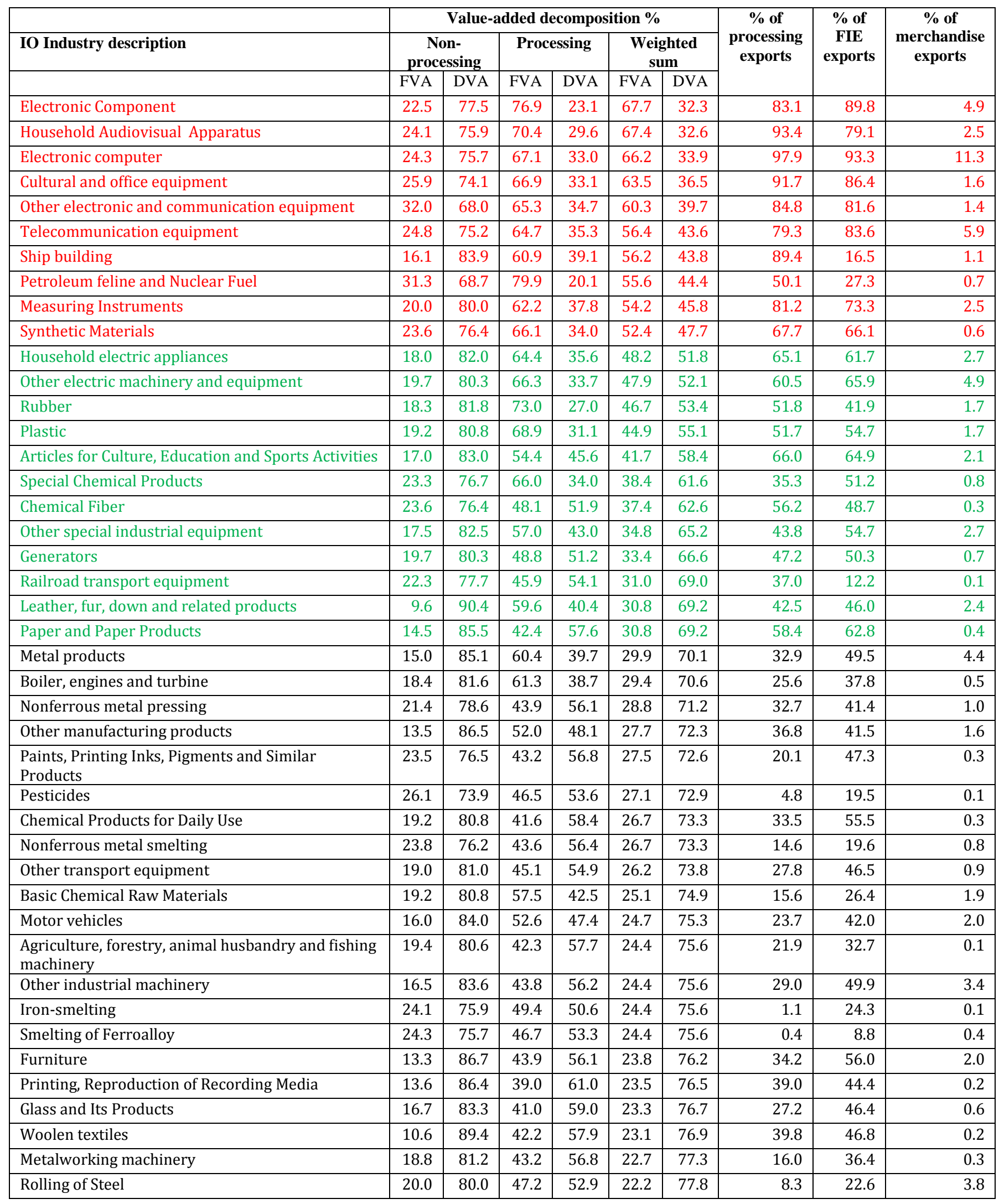




\begin{tabular}{|c|c|c|c|c|c|c|c|c|c|}
\hline Fertilizers & 19.0 & 81.0 & 42.7 & 57.3 & 22.1 & 77.9 & 13.2 & 9.5 & 0.3 \\
\hline Cotton textiles & 12.0 & 88.0 & 54.3 & 45.8 & 21.1 & 78.9 & 21.5 & 26.1 & 2.1 \\
\hline Wearing apparel & 10.5 & 89.5 & 46.1 & 53.9 & 21.0 & 79.0 & 29.7 & 36.9 & 4.6 \\
\hline Wood, Bamboo, Rattan, Palm and Straw Products & 15.4 & 84.6 & 41.7 & 58.4 & 19.6 & 80.4 & 16.1 & 33.1 & 1.0 \\
\hline Steelmaking & 19.2 & 80.8 & 48.3 & 51.7 & 19.2 & 80.8 & 0.2 & 7.1 & 0.3 \\
\hline Pottery and Porcelain & 16.6 & 83.4 & 41.9 & 58.2 & 18.0 & 82.0 & 5.2 & 29.9 & 0.5 \\
\hline Knitted and crocheted fabrics and articles & 11.8 & 88.2 & 48.4 & 51.6 & 17.5 & 82.5 & 15.6 & 25.7 & 5.7 \\
\hline Other non-metallic mineral products & 14.0 & 86.0 & 43.4 & 56.6 & 17.0 & 83.0 & 10.1 & 25.1 & 0.5 \\
\hline Hemp textiles & 13.4 & 86.6 & 43.2 & 56.8 & 16.1 & 83.9 & 9.0 & 14.7 & 0.2 \\
\hline Fire-resistant Materials & 13.5 & 86.6 & 44.9 & 55.1 & 15.3 & 84.7 & 5.8 & 51.6 & 0.1 \\
\hline Cement, Lime and Plaster & 11.0 & 89.0 & 47.1 & 52.9 & 11.6 & 88.4 & 1.7 & 29.6 & 0.1 \\
\hline
\end{tabular}

Data source: Authors' estimates. China 2002 and 2007 benchmark IO table have 84 and 90 goods producing sector respectively, they both concord to China's 4 digit classification of economic activities (GB/T 4754-2002). This concordance enable us aggregate both year's estimates to 77 consistent goods producing industries reported in this table. 
Table 7 Total Domestic Value-added Share in Chinese Gross Merchandise Exports to its Major Trading Partners, in percent, 2002 and 2007

\begin{tabular}{|c|c|c|c|c|c|c|c|c|c|c|}
\hline \multirow{2}{*}{$\begin{array}{l}\text { Region description } \\
\text { Year }\end{array}$} & \multicolumn{2}{|c|}{$\begin{array}{c}\text { Share of } \\
\text { processing exports } \\
\text { in total exports } \\
\end{array}$} & \multicolumn{2}{|c|}{ Non processing } & \multicolumn{2}{|c|}{ Processing } & \multicolumn{2}{|c|}{ Weighted-sum } & \multicolumn{2}{|c|}{$\begin{array}{l}\text { Share in total } \\
\text { exports to the } \\
\text { World } \\
\end{array}$} \\
\hline & 2002 & 2007 & 2002 & 2007 & 2002 & 2007 & 2002 & 2007 & 2002 & 2007 \\
\hline Hong Kong & 74.0 & 77.4 & 89.8 & 83.0 & 26.3 & 35.3 & 42.8 & 46.0 & 17.5 & 14.3 \\
\hline United States & 67.2 & 61.7 & 89.2 & 84.6 & 24.3 & 38.2 & 45.5 & 56.0 & 21.6 & 19.1 \\
\hline Singapore & 62.7 & 59.7 & 88.7 & 83.4 & 24.3 & 33.0 & 48.3 & 53.3 & 2.1 & 2.4 \\
\hline Taiwan province & 59.6 & 50.7 & 89.3 & 81.9 & 27.1 & 34.9 & 52.2 & 58.0 & 2.0 & 1.9 \\
\hline Malaysia & 57.6 & 52.0 & 90.4 & 84.0 & 25.5 & 33.5 & 53.0 & 57.7 & 1.5 & 1.5 \\
\hline Japan & 59.2 & 56.4 & 90.7 & 85.4 & 27.6 & 40.5 & 53.3 & 60.1 & 15.0 & 8.4 \\
\hline EU15 & 54.8 & 50.9 & 89.4 & 84.0 & 23.6 & 37.2 & 53.4 & 60.2 & 14.9 & 18.3 \\
\hline Thailand & 48.1 & 38.8 & 88.3 & 82.0 & 22.9 & 38.7 & 56.8 & 65.2 & 0.9 & 1.0 \\
\hline Rest of OECD & 46.9 & 38.5 & 89.7 & 85.4 & 25.4 & 40.3 & 59.5 & 68.0 & 1.7 & 2.1 \\
\hline Korea Rep & 45.4 & 43.2 & 90.4 & 83.5 & 27.1 & 37.0 & 61.6 & 63.4 & 4.8 & 4.7 \\
\hline Australia/NZ & 41.6 & 42.8 & 89.3 & 84.4 & 23.0 & 38.6 & 61.7 & 64.8 & 1.6 & 1.7 \\
\hline Mexico & 42.1 & 49.1 & 89.6 & 84.2 & 26.6 & 35.8 & 63.1 & 60.4 & 0.9 & 0.9 \\
\hline Philippines & 37.6 & 38.2 & 89.1 & 83.5 & 25.2 & 33.8 & 65.1 & 64.5 & 0.6 & 0.6 \\
\hline EU12 & 36.5 & 50.8 & 90.2 & 83.4 & 22.9 & 35.8 & 65.7 & 59.2 & 1.5 & 1.9 \\
\hline Brazil & 35.0 & 36.7 & 89.4 & 83.2 & 27.1 & 37.7 & 67.6 & 66.5 & 0.5 & 0.9 \\
\hline India & 24.0 & 27.0 & 89.3 & 81.7 & 21.5 & 38.6 & 73.1 & 70.1 & 0.8 & 2.0 \\
\hline Rest of Latin Am/Caribbean & 20.3 & 24.2 & 89.2 & 83.4 & 23.1 & 38.1 & 75.8 & 72.5 & 1.6 & 2.4 \\
\hline Indonesia & 20.7 & 23.4 & 89.4 & 83.3 & 25.8 & 36.1 & 76.2 & 72.2 & 1.1 & 1.1 \\
\hline Middle East/North Africa & 19.4 & 18.2 & 89.3 & 83.9 & 21.9 & 38.8 & 76.3 & 75.6 & 3.6 & 4.8 \\
\hline Eastern Europe/Central Asia & 18.9 & 16.6 & 89.4 & 85.0 & 26.3 & 39.2 & 77.5 & 77.4 & 0.9 & 2.8 \\
\hline Rest Asia & 17.2 & 18.9 & 88.6 & 83.5 & 27.0 & 41.6 & 77.9 & 75.6 & 2.2 & 2.6 \\
\hline Sub-Saharan Africa & 15.5 & 16.1 & 89.6 & 83.9 & 22.1 & 38.8 & 79.2 & 76.6 & 1.4 & 2.1 \\
\hline Russia & 15.5 & 16.9 & 90.9 & 85.6 & 30.4 & 39.3 & 81.5 & 77.8 & 1.1 & 2.4 \\
\hline World & 55.7 & 50.0 & 89.6 & 84.0 & 25.4 & 37.3 & 53.9 & 60.6 & 100.0 & 99.9 \\
\hline
\end{tabular}

Source: Authors' estimates based on China's 2002 and 2007 Benchmark input-output table published by Bureau of National Statistics and Official China trade statistics from China Customs. Input/output structure is assumed to be the same for a given export regime within a sector across all trading partners. The variation of domestic value-added by destination is due solely to variation in sector composition and the relative reliance on processing exports. 
Table 8 Domestic and Foreign content in Mexico Gross Exports, 2003

- Estimated from aggregated Mexico IO table by Mathematical Programing model

\begin{tabular}{|c|c|c|c|c|c|c|c|c|c|c|c|c|c|}
\hline & & \multicolumn{4}{|c|}{ Normal Exports } & \multicolumn{4}{|c|}{ Maquiladora exports } & \multicolumn{4}{|c|}{ Weighted Sum } \\
\hline $\begin{array}{l}\text { NAICS } \\
\text { code }\end{array}$ & NAICS description & $\begin{array}{l}\text { Direct } \\
\text { foreign } \\
\text { value- } \\
\text { added }\end{array}$ & $\begin{array}{l}\text { Direct } \\
\text { domestic } \\
\text { value- } \\
\text { added }\end{array}$ & $\begin{array}{l}\text { Total } \\
\text { Foreign } \\
\text { value- } \\
\text { added }\end{array}$ & $\begin{array}{l}\text { Total } \\
\text { Domestic } \\
\text { Value- } \\
\text { added }\end{array}$ & $\begin{array}{l}\text { Direct } \\
\text { foreign } \\
\text { value- } \\
\text { added }\end{array}$ & $\begin{array}{l}\text { Direct } \\
\text { domestic } \\
\text { value- } \\
\text { added }\end{array}$ & $\begin{array}{l}\text { Total } \\
\text { Foreign } \\
\text { value-- } \\
\text { added }\end{array}$ & $\begin{array}{l}\text { Total } \\
\text { Domestic } \\
\text { Value- } \\
\text { added }\end{array}$ & $\begin{array}{l}\text { Direct } \\
\text { foreign } \\
\text { value- } \\
\text { added }\end{array}$ & $\begin{array}{l}\text { Direct } \\
\text { domestic } \\
\text { value- } \\
\text { added }\end{array}$ & $\begin{array}{l}\text { Total } \\
\text { Foreign } \\
\text { value- } \\
\text { added }\end{array}$ & $\begin{array}{l}\text { Total } \\
\text { Domestic } \\
\text { Value- } \\
\text { added }\end{array}$ \\
\hline 311 & Food Manufacturing & 6.2 & 38.4 & 12.3 & 87.7 & 46.7 & 20.2 & 50.3 & 49.7 & 10.1 & 36.7 & 16.0 & 84.0 \\
\hline 312 & Beverage and Tobacco Product Manufacturing & 12.4 & 42.4 & 17.5 & 82.5 & 54.9 & 22.6 & 57.7 & 42.3 & 14.1 & 41.6 & 19.1 & 81.0 \\
\hline 313 & Textile Mills & 20.3 & 33.6 & 27.7 & 72.3 & 46.1 & 16.4 & 51.3 & 48.7 & 30.0 & 27.2 & 36.6 & 63.4 \\
\hline 314 & Textile Product Mills & 24.9 & 35.4 & 32.4 & 67.6 & 66.2 & 16.4 & 67.5 & 32.5 & 41.8 & 27.7 & 46.7 & 53.3 \\
\hline 315 & Apparel Manufacturing & 17.8 & 49.2 & 23.7 & 76.3 & 67.5 & 18.6 & 68.5 & 31.5 & 54.1 & 26.8 & 56.4 & 43.6 \\
\hline 316 & Leather and Allied Product Manufacturing & 11.0 & 36.4 & 19.3 & 80.7 & 64.3 & 18.7 & 65.7 & 34.3 & 27.0 & 31.1 & 33.3 & 66.8 \\
\hline 321 & Wood Product Manufacturing & 7.2 & 43.6 & 10.7 & 89.4 & 59.9 & 23.0 & 62.1 & 37.9 & 25.3 & 36.5 & 28.3 & 71.7 \\
\hline 322 & Paper Manufacturing & 11.8 & 33.1 & 19.9 & 80.1 & 57.6 & 17.0 & 59.6 & 40.4 & 27.8 & 27.5 & 33.7 & 66.3 \\
\hline 323 & Printing and Related Support Activities & 14.8 & 40.5 & 20.9 & 79.2 & 54.9 & 20.2 & 56.6 & 43.4 & 46.5 & 24.5 & 49.1 & 50.9 \\
\hline 324 & Petroleum and Coal Products Manufacturing & 4.9 & 14.3 & 10.0 & 90.0 & 56.3 & 8.1 & 60.8 & 39.2 & 5.2 & 14.3 & 10.4 & 89.7 \\
\hline 325 & Chemical Manufacturing & 12.0 & 30.6 & 17.1 & 82.9 & 48.6 & 15.8 & 50.7 & 49.3 & 13.6 & 29.9 & 18.7 & 81.4 \\
\hline 326 & Plastics and Rubber Products Manufacturing & 21.9 & 34.0 & 28.1 & 72.0 & 60.0 & 16.3 & 61.8 & 38.2 & 41.3 & 25.0 & 45.3 & 54.8 \\
\hline 327 & Nonmetallic Mineral Product Manufacturing & 7.6 & 53.6 & 11.8 & 88.2 & 45.6 & 27.6 & 47.9 & 52.1 & 15.5 & 48.2 & 19.3 & 80.7 \\
\hline 331 & Primary Metal Manufacturing & 10.5 & 36.6 & 17.5 & 82.5 & 74.6 & 18.9 & 75.4 & 24.6 & 15.0 & 35.3 & 21.7 & 78.4 \\
\hline 332 & Fabricated Metal Product Manufacturing & 18.4 & 38.6 & 24.5 & 75.5 & 57.2 & 18.2 & 59.6 & 40.5 & 37.3 & 28.7 & 41.6 & 58.4 \\
\hline 333 & Machinery Manufacturing & 18.4 & 40.9 & 25.1 & 74.9 & 60.1 & 19.0 & 61.8 & 38.2 & 35.1 & 32.1 & 39.9 & 60.2 \\
\hline 334 & Computer and Electronic Product Manufacturing & 30.6 & 39.0 & 38.0 & 62.0 & 82.4 & 8.8 & 83.1 & 16.9 & 74.6 & 13.4 & 76.3 & 23.7 \\
\hline 335 & Electrical Equipment and Component Manufacturing & 25.2 & 42.3 & 31.3 & 68.7 & 70.6 & 13.3 & 72.1 & 27.9 & 62.7 & 18.3 & 65.0 & 35.0 \\
\hline 336 & Transportation Equipment Manufacturing & 24.8 & 34.6 & 31.6 & 68.4 & 83.8 & 16.1 & 83.8 & 16.2 & 45.1 & 28.2 & 49.6 & 50.4 \\
\hline 337 & Furniture and Related Product Manufacturing & 16.3 & 47.1 & 21.2 & 78.8 & 57.9 & 21.4 & 59.6 & 40.4 & 44.5 & 29.7 & 47.2 & 52.8 \\
\hline 339 & Miscellaneous Manufacturing & 19.9 & 50.5 & 24.9 & 75.1 & 65.7 & 18.5 & 67.1 & 32.9 & 56.2 & 25.2 & 58.2 & 41.8 \\
\hline & Total & 20.4 & 36.7 & 26.9 & 73.2 & 75.8 & 13.2 & 76.8 & 23.2 & 51.2 & 23.6 & 54.6 & 45.4 \\
\hline B1 & Error at manufacture aggregate compare to true data & 1.4 & -1.0 & 2.1 & -2.1 & -0.4 & -0.3 & -0.7 & 0.7 & -3.3 & 1.0 & -2.8 & 2.8 \\
\hline B2 & Mean Absolute Percentage Error from the True Data & 22.7 & 2.9 & 17.3 & 4.3 & 16.1 & 14.1 & 14.2 & 28.0 & 18.5 & 7.8 & 15.3 & 12.4 \\
\hline B3 & Correlation with true data & 0.829 & 0.985 & 0.862 & 0.862 & 0.462 & 0.666 & 0.474 & 0.474 & 0.936 & 0.972 & 0.944 & 0.944 \\
\hline
\end{tabular}


Domestic and Foreign content in Mexico Gross Exports, 2003

- Computed directly from Mexico IO Table with Separate Maquiladora Economy Account

\begin{tabular}{|c|c|c|c|c|c|c|c|c|c|c|c|c|c|}
\hline & & \multicolumn{4}{|c|}{ Normal Exports } & \multicolumn{4}{|c|}{ Maquiladora exports } & \multicolumn{4}{|c|}{ Weighted Sum } \\
\hline $\begin{array}{l}\text { NAICS } \\
\text { code }\end{array}$ & NAICS description & $\begin{array}{l}\text { Direct } \\
\text { foreign } \\
\text { value- } \\
\text { added }\end{array}$ & $\begin{array}{l}\text { Direct } \\
\text { domestic } \\
\text { value- } \\
\text { added }\end{array}$ & $\begin{array}{l}\text { Total } \\
\text { Foreign } \\
\text { value- } \\
\text { added }\end{array}$ & $\begin{array}{l}\text { Total } \\
\text { Domestic } \\
\text { Value- } \\
\text { added }\end{array}$ & $\begin{array}{l}\text { Direct } \\
\text { foreign } \\
\text { value- } \\
\text { added }\end{array}$ & $\begin{array}{l}\text { Direct } \\
\text { domestic } \\
\text { value- } \\
\text { added }\end{array}$ & $\begin{array}{l}\text { Total } \\
\text { Foreign } \\
\text { value- } \\
\text { added }\end{array}$ & $\begin{array}{l}\text { Total } \\
\text { Domestic } \\
\text { Value- } \\
\text { added }\end{array}$ & $\begin{array}{l}\text { Direct } \\
\text { foreign } \\
\text { value- } \\
\text { added }\end{array}$ & $\begin{array}{l}\text { Direct } \\
\text { domestic } \\
\text { value- } \\
\text { added }\end{array}$ & $\begin{array}{l}\text { Total } \\
\text { Foreign } \\
\text { value- } \\
\text { added }\end{array}$ & $\begin{array}{l}\text { Total } \\
\text { Domestic } \\
\text { Value- } \\
\text { added }\end{array}$ \\
\hline 311 & Food Manufacturing & 7.6 & 38.5 & 13.3 & 86.7 & 48.9 & 23.3 & 52.0 & 48.0 & 16.7 & 35.1 & 21.8 & 78.2 \\
\hline 312 & Beverage and Tobacco Product Manufacturing & 7.2 & 42.4 & 13.0 & 87.0 & 8.8 & 19.2 & 19.6 & 80.4 & 7.3 & 41.2 & 13.4 & 86.6 \\
\hline 313 & Textile Mills & 25.0 & 34.6 & 29.9 & 70.1 & 50.5 & 19.0 & 54.8 & 45.2 & 40.5 & 25.1 & 45.0 & 55.0 \\
\hline 314 & Textile Product Mills & 18.1 & 39.5 & 24.9 & 75.1 & 71.4 & 18.6 & 72.5 & 27.5 & 59.1 & 23.4 & 61.6 & 38.4 \\
\hline 315 & Apparel Manufacturing & 15.3 & 48.7 & 21.5 & 78.5 & 63.3 & 21.5 & 65.3 & 34.7 & 53.3 & 27.2 & 56.2 & 43.8 \\
\hline 316 & Leather and Allied Product Manufacturing & 12.8 & 37.3 & 20.2 & 79.8 & 70.7 & 17.5 & 72.1 & 27.9 & 48.0 & 25.3 & 51.8 & 48.2 \\
\hline 321 & Wood Product Manufacturing & 5.1 & 43.8 & 7.9 & 92.1 & 55.8 & 24.1 & 58.1 & 41.9 & 33.0 & 32.9 & 35.6 & 64.4 \\
\hline 322 & Paper Manufacturing & 19.0 & 33.3 & 26.3 & 73.7 & 65.6 & 20.0 & 67.3 & 32.7 & 45.3 & 25.8 & 49.4 & 50.6 \\
\hline 323 & Printing and Related Support Activities & 14.2 & 40.3 & 20.7 & 79.3 & 63.4 & 19.6 & 64.9 & 35.1 & 48.6 & 25.8 & 51.6 & 48.4 \\
\hline 324 & Petroleum and Coal Products Manufacturing & 4.5 & 14.3 & 8.1 & 91.9 & 78.4 & 14.6 & 79.1 & 20.9 & 4.5 & 14.3 & 8.1 & 91.9 \\
\hline 325 & Chemical Manufacturing & 11.2 & 30.7 & 15.6 & 84.4 & 64.3 & 18.0 & 66.4 & 33.6 & 17.3 & 29.2 & 21.5 & 78.5 \\
\hline 326 & Plastics and Rubber Products Manufacturing & 22.7 & 34.7 & 27.6 & 72.4 & 64.1 & 19.0 & 66.2 & 33.8 & 52.8 & 23.3 & 55.7 & 44.3 \\
\hline 327 & Nonmetallic Mineral Product Manufacturing & 5.9 & 54.5 & 9.7 & 90.3 & 62.2 & 20.3 & 64.3 & 35.7 & 27.8 & 41.2 & 31.0 & 69.0 \\
\hline 331 & Primary Metal Manufacturing & 12.8 & 37.0 & 19.4 & 80.6 & 61.9 & 17.8 & 64.4 & 35.6 & 22.6 & 33.2 & 28.4 & 71.6 \\
\hline 332 & Fabricated Metal Product Manufacturing & 14.7 & 39.7 & 20.9 & 79.1 & 70.6 & 16.4 & 72.1 & 27.9 & 45.6 & 26.8 & 49.2 & 50.8 \\
\hline 333 & Machinery Manufacturing & 18.2 & 43.7 & 23.1 & 76.9 & 75.3 & 11.9 & 76.7 & 23.4 & 43.7 & 29.5 & 47.0 & 53.0 \\
\hline 334 & Computer and Electronic Product Manufacturing & 24.2 & 43.9 & 28.8 & 71.2 & 85.2 & 8.2 & 86.0 & 14.0 & 77.7 & 12.6 & 78.9 & 21.1 \\
\hline 335 & Electrical Equipment and Component Manufacturing & 17.8 & 41.0 & 23.5 & 76.5 & 74.2 & 13.7 & 75.7 & 24.3 & 63.5 & 18.9 & 65.8 & 34.2 \\
\hline 336 & Transportation Equipment Manufacturing & 24.8 & 35.6 & 31.2 & 68.8 & 74.3 & 16.5 & 75.3 & 24.7 & 45.8 & 27.5 & 49.9 & 50.1 \\
\hline 337 & Furniture and Related Product Manufacturing & 11.5 & 49.2 & 16.2 & 83.8 & 65.3 & 18.4 & 67.2 & 32.8 & 52.3 & 25.9 & 54.8 & 45.2 \\
\hline \multirow[t]{2}{*}{339} & Miscellaneous Manufacturing & 11.7 & 52.6 & 16.1 & 84.0 & 70.4 & 18.5 & 71.7 & 28.3 & 61.4 & 23.7 & 63.1 & 36.9 \\
\hline & Total & 19.0 & 37.7 & 24.7 & 75.3 & 76.3 & 13.4 & 77.5 & 22.5 & 54.5 & 22.6 & 57.5 & 42.6 \\
\hline
\end{tabular}




\section{Reference}

Banister, Judith, (2005), "Manufacturing employment in China” BLS Monthly Labor Review (July)

Brooke, Kendrick, Meeraus, and Raman, 2005, “GAMS -- User's Guide” GAMS Development Cooperation, Washington, DC.

Chen, X., L. Cheng, K.C. Fung and L. J. Lau. 2004. "The Estimation of Domestic Value-Added and Employment Induced by Exports: An Application to Chinese Exports to the United States," Stanford University.

Chinn, Menzie D., 2005, "Supply Capacity, Vertical Specialization and Tariff Rates: The Implications for Aggregate U.S. Trade Flow Equations,” NBER working paper 11719.

Dean, Judith M., K.C. Fung, and Zhi Wang, 2007, "Measuring the Vertical Specialization in Chinese Trade," Office of Economics Working Paper No. 2007-01-A, U.S. International Trade Commission.

Goh, Ai-Ting, and Jacques Olivier, 2004, “International Vertical Specialization, Imperfect Competition and Welfare,” HEC School of Management (France) working paper.

Koopman, Robert, Zhi Wang and Shang-jin Wei, 2008, "How much Chinese exports is really made in China - Assessing foreign and domestic value-added in gross exports," Office of Economics Working Paper No. 2008-03-B, U.S. International Trade Commission.

Krugman, Paul, 2008, “Trade and Wages, Reconsidered," paper prepared for the Brookings Paper on Economic Activity, Princeton University manuscript, February. http://www.princeton.edu/ pkrugman/pk-bpea-draft.pdf.

Lau, L.J., X. Chen, L. K. Cheng, K. C. Fung, Y. Sung, C. Yang, K. Zhu, J. Pei and Z. Tang. "Non-Competitive Input-Output Model and Its Application: An Examination of the China-U.S. Trade Surplus” Social Science in China, 2007(5): 91-103 (in Chinese).

Lawrence, Robert, 2008, Blue Collar Blues: Is Trade to Blame for Rising US Income Inequality? Peterson Institute for International Economics.

Linden, Greg, Kenneth L, Kraemer, and Jason Dedrick, 2007, "What Captures Value in a Global Innovation System?” The Paul Merage School of Business, UC Irvine, working paper.

Hummels, D., J. Ishii and K. Yi. 2001. "The Nature and Growth of Vertical Specialization in World Trade,” Journal of international economics 54:75-96. 
National Research Council , 2006, Analyzing the U.S. Content of Imports and the Foreign Content of Exports. Committee on Analyzing the U.S. Content of Imports and the Foreign Content of Exports. Center for Economics, Governance, and International Studies, Division of Behavioral and Social Sciences and Education. Washington, DC: The National Academies Press.

Rodrik, Dani, 2006, “What’s so special about China’s exports?” China \& World Economy. 14(5): 1-19, September/October.

Schott, Peter, 2008, “The relative sophistication of Chinese exports,” Economic Policy 53:5-49, January.

Varian, Hal R., 2007, “An iPod Has Global Value. Ask the (Many) Countries That Make it,” The New York Times, June 28.

Wang, Zhi, and Shang-Jin Wei, 2008, "What accounts for the rising sophistication of China’s exports?” NBER Working Paper 13771, February.

Xu, Bin, 2007, “Measuring China’s export sophistication,” China Europe International Business School working paper.

Yi, Kei-Mu, 2003. “Can Vertical Specialization Explain the Growth of World Trade?” Journal of Political Economy, vol. 111, 1: 52-102. 


\section{Appendix Table A Trade share parameters used in estimation, \%, 2007}

\begin{tabular}{|c|c|c|c|c|c|c|}
\hline IO Industry description & $\begin{array}{l}\text { Interme- } \\
\text { diates for } \\
\text { processing } \\
\text { exports } \\
\end{array}$ & $\begin{array}{l}\text { Interme- } \\
\text { diates for } \\
\text { normal use }\end{array}$ & $\begin{array}{l}\text { Capital } \\
\text { goods for } \\
\text { normal use }\end{array}$ & $\begin{array}{l}\text { Capital } \\
\text { goods for } \\
\text { Processing } \\
\text { exports } \\
\end{array}$ & $\begin{array}{l}\text { final } \\
\text { Consu } \\
\text { m-ption }\end{array}$ & $\begin{array}{l}\text { processing } \\
\text { exports }\end{array}$ \\
\hline & $(1)$ & $(2)$ & (3) & $(4)$ & $(5)$ & (6) \\
\hline Farming & 7.7 & 83.9 & & & 8.4 & 2.0 \\
\hline Forestry & 31.2 & 68.8 & & & & 3.4 \\
\hline Animal Husbandry & 30.6 & 66.9 & 2.0 & & 0.5 & 2.2 \\
\hline Fishery & 39.1 & 6.6 & & & 54.3 & 2.4 \\
\hline Services in Support of Agriculture & 14.3 & 85.7 & & & & \\
\hline Mining and Washing of Coal & & 100.0 & & & & 0.0 \\
\hline Extraction of Petroleum and Natural Gas & 8.5 & 91.5 & & & & 5.4 \\
\hline Mining of Ferrous Metal Ores & 0.0 & 100.0 & & & & \\
\hline Mining of Non-Ferrous Metal Ores & 4.3 & 95.7 & & & & 18.1 \\
\hline $\begin{array}{l}\text { Mining and Processing of Nonmetal Ores and Other } \\
\text { Ores }\end{array}$ & 45.4 & 54.6 & & & & 57.6 \\
\hline Grinding of Grains & 12.6 & 37.6 & & & 49.9 & 9.7 \\
\hline Processing of Forage & 1.9 & 94.8 & & & 3.3 & 5.5 \\
\hline Refining of Vegetable Oil & 2.7 & 93.0 & & & 4.3 & 32.9 \\
\hline Manufacture of Sugar & 13.5 & 69.6 & & & 16.9 & 18.5 \\
\hline Slaughtering and Processing of Meat & 9.8 & 28.7 & & & 61.5 & 17.0 \\
\hline Processing of Aquatic Product & 58.4 & 24.9 & & & 16.7 & 46.5 \\
\hline Processing of Other Foods & 34.4 & 22.2 & & & 43.4 & 15.2 \\
\hline Manufacture of Convenience Food & 11.4 & 11.2 & & & 77.4 & 29.5 \\
\hline Manufacture of Liquid Milk and Dairy Products & 0.9 & 61.1 & & & 37.9 & 8.6 \\
\hline Manufacture of Flavoring and Ferment Products & 53.2 & 9.1 & & & 37.7 & 17.9 \\
\hline Manufacture of Other Foods & 7.0 & 23.5 & & & 69.5 & 27.3 \\
\hline Manufacture of Alcohol and Wine & 0.5 & 1.1 & & & 98.5 & 8.6 \\
\hline Processing of Soft Drinks and Purified Tea & 7.3 & 16.8 & & & 75.8 & 30.6 \\
\hline Manufacture of Tobacco & 30.9 & 8.4 & & & 60.6 & 2.6 \\
\hline $\begin{array}{l}\text { Spinning and Weaving, Printing and Dyeing of } \\
\text { Cotton and Chemical Fiber }\end{array}$ & 90.4 & 9.5 & & & 0.0 & 21.5 \\
\hline $\begin{array}{l}\text { Spinning and Weaving, Dyeing and Finishing of } \\
\text { Wool }\end{array}$ & 73.4 & 26.5 & & & 0.2 & 39.8 \\
\hline Spinning and Weaving of Hemp and Tiffany & 61.2 & 38.8 & & & 0.0 & 9.0 \\
\hline Manufacture of Textile Products & 77.5 & 19.8 & & & 2.8 & 18.1 \\
\hline Manufacture of Knitted Fabric and Its Products & 84.4 & 5.1 & & & 10.6 & 15.6 \\
\hline $\begin{array}{l}\text { Manufacture of Textile Wearing Apparel, Footwear } \\
\text { and Caps }\end{array}$ & 57.5 & 0.0 & & & 42.5 & 29.7 \\
\hline $\begin{array}{l}\text { Manufacture of Leather, Fur, Feather(Down) and Its } \\
\text { Products }\end{array}$ & 68.1 & 23.6 & & & 8.3 & 42.5 \\
\hline $\begin{array}{l}\text { Processing of Timbers, Manufacture of Wood, } \\
\text { Bamboo, Rattan, Palm and Straw Products }\end{array}$ & 46.0 & 53.7 & & & 0.3 & 16.1 \\
\hline Manufacture of Furniture & 8.3 & 56.2 & 5.4 & 0.4 & 29.7 & 34.2 \\
\hline Manufacture of Paper and Paper Products & 28.3 & 66.2 & & & 5.5 & 58.4 \\
\hline Printing, Reproduction of Recording Media & 59.2 & 23.8 & & & 17.0 & 39.0 \\
\hline $\begin{array}{l}\text { Manufacture of Articles for Culture, Education and } \\
\text { Sports Activities }\end{array}$ & 69.9 & 6.9 & 1.9 & 4.0 & 17.3 & 66.0 \\
\hline Processing of Petroleum and Nuclear Fuel & 2.3 & 97.5 & 0.3 & & 0.0 & 50.1 \\
\hline Coking & 0.6 & 99.4 & & & & \\
\hline Manufacture of Basic Chemical Raw Materials & 19.8 & 80.2 & & & & 15.6 \\
\hline Manufacture of Fertilizers & 0.2 & 99.8 & & & & 13.2 \\
\hline Manufacture of Pesticides & 0.4 & & & & 99.6 & 4.8 \\
\hline $\begin{array}{l}\text { Manufacture of Paints, Printing Inks, Pigments and } \\
\text { Similar Products }\end{array}$ & 41.7 & 58.2 & & & 0.0 & 20.1 \\
\hline Manufacture of Synthetic Materials & 58.8 & 41.2 & & & & 67.7 \\
\hline Manufacture of Special Chemical Products & 48.2 & 50.6 & 0.0 & & 1.2 & 35.3 \\
\hline Manufacture of Chemical Products for Daily Use & 16.3 & 61.0 & & & 22.7 & 33.5 \\
\hline Manufacture of Medicines & 10.2 & 38.4 & & & 51.4 & 14.5 \\
\hline Manufacture of Chemical Fiber & 50.3 & 49.7 & & & 0.0 & 56.2 \\
\hline
\end{tabular}




\begin{tabular}{|c|c|c|c|c|c|c|}
\hline Manufacture of Rubber & 27.7 & 69.2 & & & 3.2 & 51.8 \\
\hline Manufacture of Plastic & 64.2 & 28.5 & & & 7.3 & 51.7 \\
\hline Manufacture of Cement, Lime and Plaster & 8.7 & 91.3 & & & & 1.7 \\
\hline Manufacture of Products of Cement and Plaster & 16.1 & 83.9 & & & & 26.8 \\
\hline $\begin{array}{l}\text { Manufacture of Brick, Stone and Other Building } \\
\text { Materials }\end{array}$ & 34.9 & 65.1 & & & & 9.3 \\
\hline Manufacture of Glass and Its Products & 73.4 & 25.0 & & & 1.6 & 27.2 \\
\hline Manufacture of Pottery and Porcelain & 33.1 & 62.2 & & & 4.8 & 5.2 \\
\hline Manufacture of Fire-resistant Materials & 20.0 & 80.0 & & & & 5.8 \\
\hline $\begin{array}{l}\text { Manufacture of Graphite and Other Nonmetallic } \\
\text { Mineral Products }\end{array}$ & 41.3 & 58.2 & & & 0.5 & 7.1 \\
\hline Iron-smelting & 7.9 & 92.1 & & & & 1.1 \\
\hline Steelmaking & 3.4 & 96.6 & & & & 0.2 \\
\hline Rolling of Steel & 48.7 & 51.3 & & & & 8.2 \\
\hline Smelting of Ferroalloy & 16.7 & 83.3 & & & & 0.4 \\
\hline $\begin{array}{l}\text { Smelting of Non-Ferrous Metals and Manufacture of } \\
\text { Alloys }\end{array}$ & 37.4 & 62.6 & & & & 14.5 \\
\hline Rolling of Non-Ferrous Metals & 68.0 & 32.0 & & & & 32.7 \\
\hline Manufacture of Metal Products & 42.5 & 46.6 & 3.0 & 6.1 & 1.8 & 32.9 \\
\hline Manufacture of Boiler and Prime Mover & 19.6 & 50.8 & 22.1 & 7.3 & 0.2 & 25.6 \\
\hline Manufacture of Metalworking Machinery & 2.3 & 10.5 & 30.8 & 56.4 & & 16.0 \\
\hline Manufacture of Lifters & & & 41.9 & 58.1 & & 51.8 \\
\hline Manufacture of Pump, Valve and Similar Machinery & 11.4 & 41.0 & 32.3 & 15.4 & & 23.3 \\
\hline Manufacture of Other General Purpose Machinery & 20.3 & 42.5 & 18.2 & 18.9 & 0.0 & 27.8 \\
\hline $\begin{array}{l}\text { Manufacture of Special Purpose Machinery for } \\
\text { Mining, Metallurgy and Construction }\end{array}$ & 7.6 & 34.4 & 41.1 & 17.0 & & 12.3 \\
\hline $\begin{array}{l}\text { Manufacture of Special Purpose Machinery for } \\
\text { Chemical Industry, Processing of Timber and } \\
\text { Nonmetals }\end{array}$ & 1.7 & 2.9 & 32.2 & 63.3 & & 19.3 \\
\hline $\begin{array}{l}\text { Manufacture of Special Purpose Machinery for } \\
\text { Agriculture, Forestry, Animal Husbandry and Fishery }\end{array}$ & 3.3 & 11.2 & 70.4 & 7.8 & 7.4 & 21.9 \\
\hline Manufacture of Other Special Purpose Machinery & 14.6 & 10.4 & 32.7 & 41.2 & 1.1 & 66.0 \\
\hline Manufacture of Railroad Transport Equipment & 1.9 & 68.4 & 29.7 & 0.0 & & 37.0 \\
\hline Manufacture of Automobiles & 2.3 & 49.8 & 4.8 & 0.3 & 42.7 & 23.7 \\
\hline $\begin{array}{l}\text { Manufacture of Boats and Ships and Floating } \\
\text { Devices }\end{array}$ & 21.4 & 9.5 & 65.3 & 0.8 & 3.0 & 89.4 \\
\hline Manufacture of Other Transport Equipment & 3.2 & 9.2 & 86.3 & & 1.3 & 27.7 \\
\hline Manufacture of Generators & 11.8 & 21.0 & 41.1 & 26.0 & & 47.2 \\
\hline $\begin{array}{l}\text { Manufacture of Equipments for Power Transmission } \\
\text { and Distribution and Control }\end{array}$ & 39.4 & 36.8 & 12.9 & 10.9 & & 73.9 \\
\hline $\begin{array}{l}\text { Manufacture of Wire, Cable, Optical Cable and } \\
\text { Electrical Appliances }\end{array}$ & 60.1 & 35.3 & 2.4 & 1.9 & 0.3 & 65.5 \\
\hline $\begin{array}{l}\text { Manufacture of Household Electric and Non-electric } \\
\text { Appliances }\end{array}$ & 17.7 & 18.3 & 20.3 & 37.0 & 6.8 & 65.1 \\
\hline $\begin{array}{l}\text { Manufacture of Other Electrical Machinery and } \\
\text { Equipment }\end{array}$ & 59.1 & 15.0 & 13.8 & 11.2 & 0.9 & 45.7 \\
\hline Manufacture of Communication Equipment & 36.6 & 31.6 & 22.2 & 9.5 & 0.1 & 79.3 \\
\hline Manufacture of Radar and Broadcasting Equipment & 51.3 & 16.6 & 7.0 & 4.9 & 20.2 & 84.8 \\
\hline Manufacture of Computer & 34.0 & 10.3 & 29.8 & 25.9 & & 97.9 \\
\hline Manufacture of Electronic Component & 77.0 & 18.9 & 0.9 & 2.9 & 0.3 & 83.1 \\
\hline Manufacture of Household Audiovisual Apparatus & 74.5 & 7.6 & 3.3 & 1.9 & 12.6 & 93.4 \\
\hline Manufacture of Other Electronic Equipment & 15.8 & 4.1 & 18.7 & 60.7 & 0.8 & 80.9 \\
\hline Manufacture of Measuring Instruments & 32.3 & 16.4 & 37.3 & 9.4 & 4.6 & 91.7 \\
\hline $\begin{array}{l}\text { Manufacture of Machinery for Cultural Activity \& } \\
\text { Office Work }\end{array}$ & 70.0 & 9.6 & 0.3 & 0.0 & 20.1 & 36.8 \\
\hline Manufacture of Artwork, Other Manufacture & 10.9 & 89.1 & & & & 7.9 \\
\hline Scrap and Waste & & 100.0 & & & & 41.0 \\
\hline Total Merchandise & 32.7 & 47.3 & 7.6 & 9.0 & 3.3 & 51.6 \\
\hline
\end{tabular}

Source: Source: Author's aggregation from official trade statistics from China Customs. UN BEC classification and processing trade information from China custom trade statistics were combined to identify the purpose of final use.

Note: Column (1) to (5) sum to 100. 
Appendix Table B Trade share parameters used in estimation, \%, 2002

\begin{tabular}{|c|c|c|c|c|c|c|}
\hline IO Industry description & $\begin{array}{l}\text { Interme- } \\
\text { diates for } \\
\text { processing } \\
\text { exports }\end{array}$ & $\begin{array}{l}\text { Interme- } \\
\text { diates for } \\
\text { normal use }\end{array}$ & $\begin{array}{l}\text { Capital } \\
\text { goods } \\
\text { for } \\
\text { normal } \\
\text { use }\end{array}$ & $\begin{array}{l}\text { Capital } \\
\text { goods for } \\
\text { Processing } \\
\text { exports }\end{array}$ & $\begin{array}{l}\text { final } \\
\text { Consum- } \\
\text { ption }\end{array}$ & $\begin{array}{l}\text { processing } \\
\text { exports }\end{array}$ \\
\hline & (1) & (2) & (3) & (4) & (5) & (6) \\
\hline Agriculture & 11.9 & 75.0 & & & 13.1 & 2.6 \\
\hline Forestry & 66.0 & 34.0 & & & 0.0 & 4.0 \\
\hline Logging and transport of timber and bamboo & 4.0 & 96.0 & & & & \\
\hline Animal Husbandry & 32.5 & 64.9 & 2.5 & & 0.0 & 2.8 \\
\hline Fishery & 6.0 & 0.5 & & & 93.5 & 1.2 \\
\hline $\begin{array}{l}\text { Technical services for agriculture, forestry, livestock and } \\
\text { fishing }\end{array}$ & 52.4 & & & & 47.6 & 30.0 \\
\hline Mining and Washing of Coal & 0.9 & 99.1 & & & & \\
\hline Extraction of Petroleum and Natural Gas & 11.2 & 88.8 & & & & 3.4 \\
\hline Ferrous metal ore mining & 5.9 & 94.1 & & & & \\
\hline Non-ferrous metal ore mining & 19.4 & 80.6 & & & & 7.2 \\
\hline Salt mining & 9.8 & 90.2 & & & & 1.0 \\
\hline Non-metal minerals and other mining & 70.6 & 29.4 & & & & 33.9 \\
\hline Grain mill products & 71.0 & 24.7 & & & 4.3 & 53.0 \\
\hline forage & 1.9 & 95.4 & & & 2.7 & 18.2 \\
\hline vegetable oil refining & 4.0 & 91.4 & & & 4.6 & 33.1 \\
\hline Sugar manufacturing & 32.1 & 66.7 & & & 1.2 & 87.9 \\
\hline Slaughtering and meat processing & 9.2 & 25.4 & & & 65.4 & 17.5 \\
\hline Fish and fish productions & 66.8 & 19.6 & & & 13.6 & 41.6 \\
\hline All other food manufacturing & 15.5 & 27.1 & & & 57.4 & 25.0 \\
\hline Wines, spirits and liquors & 1.8 & 2.2 & & & 96.1 & 21.0 \\
\hline Soft drink and other beverage & 5.5 & 26.5 & & & 68.0 & 15.0 \\
\hline Tobacco products & 0.5 & 0.1 & & & 99.4 & 5.0 \\
\hline Cotton textiles & 84.2 & 15.8 & & & 0.0 & 28.7 \\
\hline Woolen textiles & 86.7 & 13.3 & & & 0.1 & 37.7 \\
\hline Hemp textiles & 98.0 & 1.9 & & & 0.0 & 19.5 \\
\hline Textiles productions & 89.5 & 9.7 & & & 0.8 & 24.0 \\
\hline Knitted and crocheted fabrics and articles & 93.1 & 1.1 & & & 5.8 & 31.6 \\
\hline Wearing apparel & 87.2 & 0.0 & & & 12.8 & 45.1 \\
\hline Leather, fur, down and related products & 91.1 & 7.6 & & & 1.3 & 54.3 \\
\hline Products of wood, bamboo, cane, palm, straw & 59.0 & 41.0 & & & & 19.6 \\
\hline Furniture & 28.0 & 42.7 & 7.3 & 1.8 & 20.3 & 47.2 \\
\hline Paper and paper products & 36.9 & 62.8 & & & 0.3 & 50.7 \\
\hline Printing, reproduction of recording media & 71.6 & 8.8 & & & 19.5 & 83.0 \\
\hline Stationary and related products & 31.1 & 60.9 & & & 8.0 & 39.4 \\
\hline Toys, sporting and athletic and recreation products & 80.4 & 1.2 & 0.3 & 6.8 & 11.3 & 72.9 \\
\hline Petroleum and nuclear processing & 2.5 & 97.1 & 0.4 & 0.0 & & 32.1 \\
\hline Coking & 3.7 & 96.3 & & & & 2.6 \\
\hline Basic chemicals & 25.8 & 74.2 & & & & 11.7 \\
\hline Chemical fertilizers & 0.2 & 99.8 & & & & 4.5 \\
\hline Chemical pesticides & 5.2 & & & & 94.8 & 6.2 \\
\hline $\begin{array}{l}\text { paints, varnishes and similar coatings, printing ink and } \\
\text { mastics }\end{array}$ & 50.4 & 49.6 & & & 0.0 & 29.1 \\
\hline Man-made chemical products & 59.7 & 40.3 & & & & 58.3 \\
\hline Special chemical products & 65.9 & 33.1 & 0.0 & 0.0 & 1.1 & 46.9 \\
\hline Chemical products for daily use & 33.9 & 53.1 & & & 12.9 & 36.3 \\
\hline Medical and pharmaceutical products & 5.8 & 40.1 & & & 54.1 & 16.9 \\
\hline Chemical fibers & 44.1 & 55.9 & & & & 20.5 \\
\hline Rubber products & 42.5 & 54.2 & & & 3.3 & 53.1 \\
\hline Plastic products & 70.6 & 25.3 & & & 4.1 & 64.5 \\
\hline Cement, lime and plaster & 14.0 & 86.0 & & & & 7.0 \\
\hline
\end{tabular}




\begin{tabular}{|c|c|c|c|c|c|c|}
\hline IO Industry description & $\begin{array}{l}\text { Interme- } \\
\text { diates for } \\
\text { processing } \\
\text { exports }\end{array}$ & $\begin{array}{l}\text { Interme- } \\
\text { diates for } \\
\text { normal use }\end{array}$ & $\begin{array}{l}\text { Capital } \\
\text { goods } \\
\text { for } \\
\text { normal } \\
\text { use } \\
\end{array}$ & $\begin{array}{l}\text { Capital } \\
\text { goods for } \\
\text { Processing } \\
\text { exports }\end{array}$ & $\begin{array}{l}\text { final } \\
\text { Consum- } \\
\text { ption }\end{array}$ & $\begin{array}{l}\text { processing } \\
\text { exports }\end{array}$ \\
\hline Glass and glass products & 73.7 & 25.6 & & & 0.7 & 33.0 \\
\hline Pottery, china and earthenware & 39.8 & 55.4 & & & 4.8 & 11.4 \\
\hline Fireproof materials & 33.6 & 66.4 & & & & 19.1 \\
\hline Other non-metallic mineral products & 42.9 & 56.3 & & & 0.8 & 14.0 \\
\hline Iron-smelting & 5.4 & 94.6 & & & & 23.7 \\
\hline Steel-smelting & 36.2 & 63.8 & & & & 58.8 \\
\hline Steel pressing & 37.6 & 62.4 & & & & 16.0 \\
\hline Alloy iron smelting & 8.1 & 91.9 & & & & 40.8 \\
\hline Nonferrous metal smelting & 24.3 & 75.7 & & & & 45.0 \\
\hline Nonferrous metal pressing & 68.4 & 31.6 & & & & 46.9 \\
\hline Metal products & 32.9 & 33.7 & 5.9 & 27.1 & 0.5 & 43.2 \\
\hline Boiler, engines and turbine & 8.8 & 64.2 & 21.7 & 5.2 & 0.1 & 26.6 \\
\hline Metalworking machinery & 3.7 & 9.5 & 28.1 & 58.8 & & 13.3 \\
\hline Other general industrial machinery & 20.7 & 18.5 & 18.8 & 41.6 & 0.4 & 43.7 \\
\hline $\begin{array}{l}\text { Agriculture, forestry, animal husbandry and fishing } \\
\text { machinery }\end{array}$ & 2.3 & 10.7 & 62.4 & 17.2 & 7.4 & 17.8 \\
\hline Other special industrial equipment & 7.4 & 8.6 & 35.5 & 47.9 & 0.5 & 39.9 \\
\hline Railroad transport equipment & 0.3 & 31.9 & 67.8 & 0.0 & & 19.9 \\
\hline Motor vehicles & 0.6 & 2.1 & 87.7 & 9.3 & 0.3 & 37.8 \\
\hline Parts and accessories for motor vehicles and their engines & 4.1 & 95.9 & & & & 34.3 \\
\hline Ship building & 8.0 & 40.3 & 45.7 & 5.3 & 0.7 & 95.8 \\
\hline Other transport equipment & 9.5 & 30.7 & 59.8 & & 0.0 & 41.2 \\
\hline Generators & 22.9 & 12.5 & 28.3 & 36.2 & & 76.8 \\
\hline Household electric appliances & 63.6 & 23.5 & 1.0 & 0.5 & 11.3 & 79.1 \\
\hline Other electric machinery and equipment & 53.5 & 18.6 & 8.8 & 18.9 & 0.2 & 66.8 \\
\hline Telecommunication equipment & 4.2 & 17.4 & 74.6 & 3.8 & 0.0 & 91.2 \\
\hline Electronic computer & & & 91.8 & 8.2 & & 99.1 \\
\hline Other computer peripheral equipment & 54.4 & 12.4 & 20.4 & 12.9 & & 99.2 \\
\hline Electronic element and device & 80.6 & 17.7 & 0.2 & 1.5 & & 89.7 \\
\hline $\begin{array}{l}\text { Radio, television and communication equipment and } \\
\text { apparatus }\end{array}$ & 76.3 & 4.3 & 8.2 & 6.9 & 4.4 & 90.6 \\
\hline Other electronic and communication equipment & 45.0 & 50.9 & 3.5 & 0.6 & & 84.9 \\
\hline Instruments, meters and other measuring equipment & 10.7 & 3.4 & 18.1 & 66.8 & 0.9 & 68.6 \\
\hline Cultural and office equipment & 54.1 & 11.2 & 18.6 & 14.5 & 1.6 & 93.4 \\
\hline Arts and crafts products & 93.3 & 1.4 & & & 5.3 & 53.8 \\
\hline Other manufacturing products & 91.4 & 5.4 & 0.2 & 0.0 & 3.0 & 48.8 \\
\hline Scrap and waste & 9.0 & 91.0 & & & & 26.0 \\
\hline Total Merchandise & 38.0 & 39.1 & 11.0 & 10.2 & 1.8 & 55.9 \\
\hline
\end{tabular}

Source: Source: Author's aggregation from official trade statistics from China Customs. UN BEC classification and processing trade information from China custom trade statistics were combined to identify the purpose of final use.

Note: Column (1) to (5) sum to 100. 


\section{Appendix Table C Trade share parameters used in estimation, \%, 1997}

\begin{tabular}{|c|c|c|c|c|c|c|}
\hline Description & $\begin{array}{l}\text { Interme- } \\
\text { diates for } \\
\text { processing } \\
\text { exports }\end{array}$ & $\begin{array}{l}\text { Interme- } \\
\text { diates for } \\
\text { normal use }\end{array}$ & $\begin{array}{l}\text { Capital } \\
\text { goods } \\
\text { for } \\
\text { normal } \\
\text { use } \\
\end{array}$ & $\begin{array}{l}\text { Capital } \\
\text { goods for } \\
\text { Processing } \\
\text { exports }\end{array}$ & $\begin{array}{l}\text { final } \\
\text { Consum- } \\
\text { ption }\end{array}$ & $\begin{array}{l}\text { processing } \\
\text { exports }\end{array}$ \\
\hline & (1) & (2) & (3) & (4) & (5) & (6) \\
\hline Crop cultivation & 43.7 & 51.7 & & & 4.7 & 2.9 \\
\hline Forestry & 45.9 & 26.2 & & & 27.8 & 3.6 \\
\hline Livestock and livestock products & 69.9 & 29.3 & 0.7 & & 0.1 & 3.5 \\
\hline Fishery & 16.7 & 0.0 & & & 83.3 & 8.8 \\
\hline Other agricultural products & 77.8 & 10.6 & & & 11.5 & 11.5 \\
\hline Coal mining and processing & 36.0 & 64.0 & & & & \\
\hline Crude petroleum products & 22.2 & 77.8 & & & & 0.0 \\
\hline Natural gas products & & 100.0 & & & & \\
\hline Ferrous ore mining & 53.4 & 46.6 & & & & \\
\hline Non-ferrous ore mining & 57.2 & 42.8 & & & & 8.2 \\
\hline Salt mining & 43.9 & 56.1 & & & & 0.9 \\
\hline Non-metal minerals and other mining & 84.7 & 15.3 & & & & 22.6 \\
\hline Logging and transport of timber and bamboo & 27.5 & 72.5 & & & & 5.9 \\
\hline Grain mill products, vegetable oil and forage & 23.6 & 76.0 & & & 0.4 & 51.6 \\
\hline Sugar refining & 51.1 & 48.4 & & & 0.5 & 88.5 \\
\hline Slaughtering, meat processing, eggs and dairy products & 71.6 & 22.8 & & & 5.6 & 15.4 \\
\hline Prepared fish and seafood & 93.3 & 1.7 & & & 5.0 & 41.7 \\
\hline Other food products & 43.3 & 21.8 & & & 34.9 & 26.3 \\
\hline Wines, spirits and liquors & 5.8 & 3.9 & & & 90.3 & 18.2 \\
\hline Non-alcoholic beverage & 69.3 & 2.5 & & & 28.1 & 15.9 \\
\hline Tobacco products & 1.4 & 0.1 & & & 98.5 & 7.7 \\
\hline Cotton textiles & 98.7 & 1.3 & & & 0.0 & 40.8 \\
\hline Woolen textiles & 93.7 & 6.2 & & & 0.0 & 64.1 \\
\hline Hemp textiles & 95.4 & 4.6 & & & 0.0 & 30.9 \\
\hline Silk textiles & 96.2 & 3.8 & & & 0.0 & 5.9 \\
\hline Knitted mills & 98.0 & 1.1 & & & 0.9 & 37.3 \\
\hline Other textiles & 98.6 & 1.4 & & & 0.0 & 57.0 \\
\hline Wearing apparel & 97.4 & 0.0 & & & 2.5 & 54.8 \\
\hline Leather, furs, down and related products & 98.3 & 1.0 & & & 0.7 & 72.1 \\
\hline Sawmills and fiberboard & 72.3 & 27.7 & & & & 22.3 \\
\hline $\begin{array}{l}\text { Furniture and products of wood, bamboo, cane, palm, } \\
\text { straw, etc. }\end{array}$ & 57.7 & 16.1 & 6.0 & 4.0 & 16.3 & 42.5 \\
\hline Paper and products & 54.1 & 45.7 & & & 0.1 & 61.7 \\
\hline Printing and record medium reproduction & 76.2 & 22.6 & & & 1.1 & 78.5 \\
\hline Cultural goods & 16.0 & 83.3 & & & 0.6 & 59.7 \\
\hline Toys, sporting and athletic and recreation products & 64.8 & 0.4 & 4.2 & 23.4 & 7.2 & 75.6 \\
\hline Petroleum refining & 8.9 & 91.1 & & & & 46.6 \\
\hline Coking & 13.9 & 86.1 & & & & 3.6 \\
\hline Raw chemical materials & 53.1 & 46.9 & & & & 5.5 \\
\hline Chemical fertilizers & 0.3 & 99.7 & & & & 3.2 \\
\hline Chemical pesticides & 6.9 & 0.8 & & & 92.3 & 21.2 \\
\hline Organic chemical products & 50.7 & 49.3 & & & 0.0 & 17.8 \\
\hline Chemical products for daily use & 64.2 & 20.8 & & & 15.0 & 39.2 \\
\hline Other chemical products & 78.6 & 21.3 & 0.0 & 0.0 & 0.2 & 38.2 \\
\hline Medical and pharmaceutical products & 16.9 & 28.6 & & & 54.4 & 16.8 \\
\hline Chemical fibers & 79.8 & 20.2 & & & 0.0 & 69.9 \\
\hline
\end{tabular}




\begin{tabular}{|c|c|c|c|c|c|c|}
\hline Description & $\begin{array}{l}\text { Interme- } \\
\text { diates for } \\
\text { processing } \\
\text { exports }\end{array}$ & $\begin{array}{l}\text { Interme- } \\
\text { diates for } \\
\text { normal use }\end{array}$ & $\begin{array}{l}\text { Capital } \\
\text { goods } \\
\text { for } \\
\text { normal } \\
\text { use } \\
\end{array}$ & $\begin{array}{l}\text { Capital } \\
\text { goods for } \\
\text { Processing } \\
\text { exports }\end{array}$ & $\begin{array}{l}\text { final } \\
\text { Consum- } \\
\text { ption }\end{array}$ & $\begin{array}{l}\text { processing } \\
\text { exports }\end{array}$ \\
\hline Rubber products & 73.7 & 25.8 & & & 0.5 & 69.0 \\
\hline Plastic products & 88.6 & 9.2 & & & 2.2 & 74.3 \\
\hline Cement & 12.4 & 87.6 & & & & 4.6 \\
\hline Cement and asbestos products & 68.1 & 31.9 & & & & 53.7 \\
\hline Bricks, tiles, lime and light-weight building materials & 52.7 & 47.3 & & & 0.0 & 9.7 \\
\hline Glass and glass products & 78.6 & 20.4 & & & 1.0 & 41.5 \\
\hline Pottery, china and earthenware & 66.8 & 29.9 & & & 3.3 & 14.8 \\
\hline Fireproof products & 67.0 & 33.0 & & & & 7.6 \\
\hline Other non-metallic mineral products & 83.8 & 15.6 & & & 0.6 & 19.0 \\
\hline Iron-smelting & 78.1 & 21.9 & & & & 91.0 \\
\hline Steel-smelting & 23.8 & 76.2 & & & & 78.1 \\
\hline Steel processing & 62.1 & 37.9 & & & & 82.9 \\
\hline Alloy iron smelting & 52.5 & 47.5 & & & & 46.4 \\
\hline Nonferrous metal smelting & 45.0 & 55.0 & & & & 38.0 \\
\hline Nonferrous metal processing & 83.3 & 16.7 & & & & 46.6 \\
\hline Metal products & 58.9 & 19.7 & 2.5 & 18.3 & 0.6 & 42.7 \\
\hline Boiler, engines and turbine & 23.9 & 48.4 & 13.4 & 14.2 & 0.2 & 31.5 \\
\hline Metalworking machinery & 10.2 & 9.3 & 17.9 & 62.6 & & 22.6 \\
\hline Other general industrial machinery & 22.8 & 14.1 & 18.6 & 44.2 & 0.2 & 43.7 \\
\hline $\begin{array}{l}\text { Agriculture, forestry, animal husbandry and fishing } \\
\text { machinery }\end{array}$ & 9.9 & 4.0 & 37.1 & 46.4 & 2.7 & 7.7 \\
\hline Other special industrial equipment & 12.9 & 5.6 & 16.7 & 64.7 & 0.1 & 41.5 \\
\hline Railroad transport equipment & 11.1 & 28.2 & 59.8 & 0.8 & & 47.4 \\
\hline Motor vehicles & 4.1 & 64.5 & 25.6 & 5.8 & 0.1 & 38.1 \\
\hline Ship building & 12.0 & 4.9 & 25.6 & 56.6 & 0.9 & 89.7 \\
\hline Aircraft & 2.7 & 17.1 & 78.0 & 1.4 & 0.8 & 23.3 \\
\hline Bicycle & 89.6 & 10.0 & & & 0.4 & 80.7 \\
\hline Other transport machinery & 17.5 & 81.8 & & & 0.7 & 40.7 \\
\hline Generators & 29.6 & 5.5 & 19.5 & 45.3 & & 85.2 \\
\hline Household electric appliances & 40.8 & 11.3 & 4.4 & 35.0 & 8.5 & 80.9 \\
\hline Other electric machinery and equipment & 54.3 & 11.6 & 9.5 & 23.9 & 0.7 & 76.7 \\
\hline Electronic computer & 69.2 & 3.9 & 13.4 & 13.5 & & 97.2 \\
\hline Electronic appliances & 93.5 & 2.6 & 1.8 & 2.0 & 0.1 & 96.8 \\
\hline Electronic element and device & 74.9 & 17.4 & 0.8 & 6.8 & & 85.1 \\
\hline Other electronic and communication equipment & 18.5 & 25.4 & 47.0 & 3.5 & 5.5 & 92.3 \\
\hline Instruments, meters and other measuring equipment & 37.3 & 5.0 & 24.5 & 33.0 & 0.2 & 77.7 \\
\hline Cultural and office equipment & 89.5 & 3.2 & 4.6 & 2.4 & 0.3 & 98.4 \\
\hline Arts and crafts products & 89.3 & 2.2 & & & 8.5 & 55.2 \\
\hline Other manufacturing products & 96.6 & 2.1 & 0.0 & 0.0 & 1.3 & 71.2 \\
\hline Total Merchandise & 51.2 & 28.2 & 7.3 & 12.1 & 1.3 & 55.1 \\
\hline
\end{tabular}

Source: Author's aggregation from official trade statistics from China Customs. UN BEC classification and processing trade information from China custom trade statistics were combined to identify the purpose of final use.

Note: Column (1) to (5) sum to 100. 


\section{Appendix Table D Domestic and foreign value-added embodied in Chinese gross merchandise exports, in percent, 2007}

\begin{tabular}{|c|c|c|c|c|c|c|c|c|}
\hline \multirow[b]{2}{*}{ IO industry description } & \multicolumn{4}{|c|}{ Split Method } & \multicolumn{4}{|c|}{ HIY Method } \\
\hline & $\begin{array}{l}\text { Direct } \\
\text { foreign } \\
\text { value- } \\
\text { added }\end{array}$ & $\begin{array}{l}\text { Direct } \\
\text { domestic } \\
\text { value- } \\
\text { added } \\
\end{array}$ & $\begin{array}{l}\text { Total } \\
\text { Foreign } \\
\text { value- } \\
\text { added }\end{array}$ & $\begin{array}{l}\text { Total } \\
\text { Domestic } \\
\text { Value- } \\
\text { added }\end{array}$ & $\begin{array}{l}\text { Direct } \\
\text { foreign } \\
\text { value- } \\
\text { added }\end{array}$ & $\begin{array}{l}\text { Direct } \\
\text { domestic } \\
\text { value- } \\
\text { added }\end{array}$ & $\begin{array}{l}\text { Total } \\
\text { Foreign } \\
\text { value- } \\
\text { added }\end{array}$ & $\begin{array}{l}\text { Total } \\
\text { Domestic } \\
\text { Value- } \\
\text { added }\end{array}$ \\
\hline Farming & 1.6 & 64.6 & 6.2 & 93.8 & 1.8 & 64.9 & 7.1 & 92.9 \\
\hline Forestry & 5.3 & 67.9 & 8.8 & 91.3 & 2.6 & 68.5 & 7.0 & 93.0 \\
\hline Animal Husbandry & 1.7 & 48.1 & 6.2 & 93.8 & 1.4 & 48.4 & 6.7 & 93.3 \\
\hline Fishery & 1.8 & 60.9 & 6.2 & 93.8 & 1.0 & 61.3 & 6.3 & 93.7 \\
\hline Services in Support of Agriculture & 3.5 & 47.5 & 9.0 & 91.0 & 2.4 & 47.5 & 9.3 & 90.7 \\
\hline Mining and Washing of Coal & 2.2 & 45.9 & 9.1 & 90.9 & 2.7 & 45.9 & 11.4 & 88.6 \\
\hline Extraction of Petroleum and Natural Gas & 5.8 & 57.4 & 11.7 & 88.3 & 3.7 & 59.7 & 11.1 & 88.9 \\
\hline Mining of Ferrous Metal Ores & 10.0 & 33.3 & 18.7 & 81.3 & 8.8 & 33.3 & 19.9 & 80.1 \\
\hline Mining of Non-Ferrous Metal Ores & 15.1 & 33.8 & 23.3 & 76.8 & 6.6 & 37.9 & 17.6 & 82.5 \\
\hline Mining and Processing of Nonmetal Ores and Other Ores & 29.3 & 26.7 & 35.8 & 64.2 & 4.8 & 39.2 & 15.5 & 84.5 \\
\hline Grinding of Grains & 8.5 & 18.2 & 13.9 & 86.1 & 5.3 & 19.2 & 11.8 & 88.2 \\
\hline Processing of Forage & 6.9 & 16.3 & 13.3 & 86.7 & 5.5 & 16.7 & 13.3 & 86.7 \\
\hline Refining of Vegetable Oil & 14.7 & 16.1 & 21.1 & 79.0 & 7.8 & 18.9 & 15.3 & 84.7 \\
\hline Manufacture of Sugar & 12.5 & 19.3 & 18.5 & 81.5 & 5.0 & 21.8 & 12.1 & 87.9 \\
\hline Slaughtering and Processing of Meat & 7.2 & 15.2 & 13.0 & 87.0 & 2.2 & 16.3 & 8.9 & 91.1 \\
\hline Processing of Aquatic Product & 14.5 & 16.9 & 19.4 & 80.7 & 2.7 & 21.1 & 9.4 & 90.7 \\
\hline Processing of Other Foods & 13.6 & 15.3 & 19.7 & 80.3 & 4.9 & 17.1 & 13.0 & 87.1 \\
\hline Manufacture of Convenience Food & 14.5 & 16.5 & 22.4 & 77.6 & 3.8 & 20.7 & 13.9 & 86.1 \\
\hline Manufacture of Liquid Milk and Dairy Products & 8.1 & 17.6 & 15.5 & 84.5 & 4.4 & 18.7 & 13.8 & 86.2 \\
\hline Manufacture of Flavoring and Ferment Products & 16.3 & 17.4 & 23.2 & 76.8 & 5.3 & 19.7 & 14.9 & 85.1 \\
\hline Manufacture of Other Foods & 18.6 & 18.6 & 25.1 & 74.9 & 5.5 & 22.5 & 14.7 & 85.3 \\
\hline Manufacture of Alcohol and Wine & 7.0 & 32.3 & 13.3 & 86.8 & 3.4 & 34.3 & 11.1 & 88.9 \\
\hline Processing of Soft Drinks and Purified Tea & 14.7 & 19.9 & 22.8 & 77.2 & 4.9 & 24.9 & 15.8 & 84.2 \\
\hline Manufacture of Tobacco & 3.2 & 61.1 & 6.8 & 93.2 & 2.1 & 62.4 & 6.6 & 93.4 \\
\hline $\begin{array}{l}\text { Spinning and Weaving, Printing and Dyeing of Cotton and } \\
\text { Chemical Fiber }\end{array}$ & 12.0 & 15.8 & 21.1 & 78.9 & 4.5 & 17.8 & 17.5 & 82.5 \\
\hline Spinning and Weaving, Dyeing and Finishing of Wool & 15.4 & 16.2 & 23.1 & 76.9 & 3.3 & 21.4 & 13.1 & 86.9 \\
\hline Spinning and Weaving of Hemp and Tiffany & 7.5 & 18.1 & 16.1 & 83.9 & 4.3 & 19.0 & 15.1 & 84.9 \\
\hline Manufacture of Textile Products & 8.8 & 20.0 & 17.6 & 82.4 & 4.0 & 21.3 & 16.6 & 83.4 \\
\hline Manufacture of Knitted Fabric and Its Products & 8.1 & 21.9 & 17.5 & 82.5 & 4.3 & 22.1 & 17.7 & 82.3 \\
\hline Manufacture of Textile Wearing Apparel, Footwear and Caps & 13.0 & 21.1 & 21.0 & 79.0 & 4.3 & 23.8 & 16.4 & 83.6 \\
\hline Manufacture of Leather, Fur, Feather(Down) and Its Products & 24.4 & 15.9 & 30.8 & 69.2 & 6.6 & 20.1 & 18.0 & 82.0 \\
\hline $\begin{array}{l}\text { Processing of Timbers, Manufacture of Wood, Bamboo, } \\
\text { Rattan, Palm and Straw Products }\end{array}$ & 10.2 & 20.5 & 19.6 & 80.4 & 7.9 & 22.5 & 19.6 & 80.4 \\
\hline Manufacture of Furniture & 14.5 & 21.9 & 23.8 & 76.2 & 5.0 & 25.6 & 18.1 & 81.9 \\
\hline Manufacture of Paper and Paper Products & 22.3 & 13.9 & 30.8 & 69.2 & 8.2 & 21.8 & 20.1 & 79.9 \\
\hline Printing, Reproduction of Recording Media & 14.4 & 24.5 & 23.5 & 76.5 & 4.9 & 30.5 & 18.0 & 82.0 \\
\hline $\begin{array}{l}\text { Manufacture of Articles for Culture, Education and Sports } \\
\text { Activities }\end{array}$ & 33.8 & 16.7 & 41.7 & 58.4 & 8.3 & 21.4 & 24.2 & 75.9 \\
\hline Processing of Petroleum and Nuclear Fuel & 50.9 & 10.8 & 55.6 & 44.4 & 26.3 & 15.3 & 34.7 & 65.3 \\
\hline Coking & 3.4 & 32.1 & 10.4 & 89.6 & 3.2 & 32.1 & 12.0 & 88.0 \\
\hline Manufacture of Basic Chemical Raw Materials & 14.6 & 19.2 & 25.1 & 74.9 & 9.9 & 20.9 & 23.4 & 76.6 \\
\hline Manufacture of Fertilizers & 11.5 & 17.5 & 22.1 & 77.9 & 8.5 & 18.9 & 22.3 & 77.7 \\
\hline Manufacture of Pesticides & 14.7 & 18.6 & 27.1 & 72.9 & 11.8 & 19.2 & 27.1 & 72.9 \\
\hline $\begin{array}{l}\text { Manufacture of Paints, Printing Inks, Pigments and Similar } \\
\text { Products }\end{array}$ & 14.6 & 15.7 & 27.5 & 72.6 & 11.6 & 18.0 & 27.9 & 72.1 \\
\hline Manufacture of Synthetic Materials & 41.5 & 11.2 & 52.4 & 47.7 & 12.8 & 20.9 & 29.9 & 70.1 \\
\hline Manufacture of Special Chemical Products & 28.2 & 13.1 & 38.4 & 61.6 & 13.2 & 15.4 & 28.5 & 71.5 \\
\hline Manufacture of Chemical Products for Daily Use & 17.4 & 20.7 & 26.7 & 73.3 & 9.5 & 26.3 & 22.4 & 77.6 \\
\hline Manufacture of Medicines & 12.7 & 26.4 & 19.7 & 80.3 & 5.8 & 29.0 & 15.4 & 84.6 \\
\hline Manufacture of Chemical Fiber & 26.8 & 10.9 & 37.4 & 62.6 & 13.2 & 16.7 & 30.2 & 69.8 \\
\hline
\end{tabular}




\begin{tabular}{|c|c|c|c|c|c|c|c|c|}
\hline \multirow[b]{2}{*}{ IO industry description } & \multicolumn{4}{|c|}{ Split Method } & \multicolumn{4}{|c|}{ HIY Method } \\
\hline & $\begin{array}{l}\text { Direct } \\
\text { foreign } \\
\text { value- } \\
\text { added } \\
\end{array}$ & $\begin{array}{l}\text { Direct } \\
\text { domestic } \\
\text { value- } \\
\text { added }\end{array}$ & \begin{tabular}{|l|} 
Total \\
Foreign \\
value- \\
added \\
\end{tabular} & $\begin{array}{l}\text { Total } \\
\text { Domestic } \\
\text { Value- } \\
\text { added }\end{array}$ & $\begin{array}{l}\text { Direct } \\
\text { foreign } \\
\text { value- } \\
\text { added } \\
\end{array}$ & $\begin{array}{l}\text { Direct } \\
\text { domestic } \\
\text { value- } \\
\text { added }\end{array}$ & \begin{tabular}{|l|} 
Total \\
Foreign \\
value- \\
added \\
\end{tabular} & $\begin{array}{l}\text { Total } \\
\text { Domestic } \\
\text { Value- } \\
\text { added }\end{array}$ \\
\hline Manufacture of Rubber & 38.9 & 14.1 & 46.7 & 53.4 & 11.6 & 19.7 & 26.6 & 73.4 \\
\hline Manufacture of Plastic & 35.6 & 13.1 & 44.9 & 55.1 & 11.5 & 18.5 & 29.6 & 70.4 \\
\hline Manufacture of Cement, Lime and Plaster & 3.3 & 27.6 & 11.6 & 88.4 & 3.1 & 27.8 & 13.9 & 86.1 \\
\hline Manufacture of Products of Cement and Plaster & 11.9 & 20.4 & 21.1 & 78.9 & 2.7 & 24.6 & 14.6 & 85.4 \\
\hline Manufacture of Brick, Stone and Other Building Materials & 6.8 & 23.1 & 16.6 & 83.4 & 4.9 & 24.4 & 17.1 & 82.9 \\
\hline Manufacture of Glass and Its Products & 13.8 & 23.6 & 23.3 & 76.7 & 7.5 & 27.4 & 19.9 & 80.1 \\
\hline Manufacture of Pottery and Porcelain & 7.8 & 25.5 & 18.0 & 82.0 & 5.6 & 26.0 & 18.5 & 81.5 \\
\hline Manufacture of Fire-resistant Materials & 7.8 & 37.4 & 15.3 & 84.7 & 4.1 & 39.0 & 13.6 & 86.4 \\
\hline $\begin{array}{l}\text { Manufacture of Graphite and Other Nonmetallic Mineral } \\
\text { Products }\end{array}$ & 7.9 & 29.3 & 16.6 & 83.4 & 3.9 & 30.3 & 15.0 & 85.0 \\
\hline Iron-smelting & 15.7 & 18.9 & 24.4 & 75.6 & 14.6 & 19.0 & 24.7 & 75.3 \\
\hline Steelmaking & 9.4 & 27.6 & 19.2 & 80.8 & 9.4 & 27.6 & 20.3 & 79.7 \\
\hline Rolling of Steel & 9.6 & 16.9 & 22.2 & 77.8 & 8.7 & 17.7 & 23.0 & 77.0 \\
\hline Smelting of Ferroalloy & 15.0 & 26.3 & 24.4 & 75.6 & 12.5 & 26.3 & 23.6 & 76.4 \\
\hline Smelting of Non-Ferrous Metals and Manufacture of Alloys & 16.3 & 15.2 & 26.7 & 73.3 & 15.5 & 16.8 & 27.5 & 72.5 \\
\hline Rolling of Non-Ferrous Metals & 15.8 & 16.7 & 28.8 & 71.2 & 9.4 & 20.9 & 26.4 & 73.6 \\
\hline Manufacture of Metal Products & 19.2 & 17.2 & 29.9 & 70.1 & 5.0 & 20.8 & 20.5 & 79.5 \\
\hline Manufacture of Boiler and Prime Mover & 19.4 & 20.2 & 29.4 & 70.6 & 9.3 & 23.2 & 23.8 & 76.2 \\
\hline Manufacture of Metalworking Machinery & 11.5 & 22.3 & 22.7 & 77.3 & 8.1 & 24.7 & 23.1 & 76.9 \\
\hline Manufacture of Lifters & 20.0 & 14.3 & 30.8 & 69.2 & 6.5 & 19.6 & 22.8 & 77.2 \\
\hline Manufacture of Pump, Valve and Similar Machinery & 11.7 & 20.8 & 23.0 & 77.0 & 7.2 & 23.3 & 21.9 & 78.1 \\
\hline Manufacture of Other General Purpose Machinery & 12.6 & 19.2 & 23.8 & 76.2 & 7.4 & 23.0 & 22.4 & 77.6 \\
\hline $\begin{array}{l}\text { Manufacture of Special Purpose Machinery for Mining, } \\
\text { Metallurgy and Construction }\end{array}$ & 10.9 & 21.5 & 22.1 & 77.9 & 6.8 & 23.1 & 21.7 & 78.3 \\
\hline $\begin{array}{l}\text { Manufacture of Special Purpose Machinery for Chemical } \\
\text { Industry, Processing of Timber and Nonmetals }\end{array}$ & 11.0 & 22.9 & 22.1 & 78.0 & 5.4 & 25.9 & 19.9 & 80.1 \\
\hline $\begin{array}{l}\text { Manufacture of Special Purpose Machinery for Agriculture, } \\
\text { Forestry, Animal Husbandry and Fishery }\end{array}$ & 13.1 & 18.9 & 24.4 & 75.6 & 6.0 & 21.3 & 21.7 & 78.4 \\
\hline Manufacture of Other Special Purpose Machinery & 36.7 & 16.2 & 44.3 & 55.7 & 10.7 & 23.3 & 25.4 & 74.6 \\
\hline Manufacture of Railroad Transport Equipment & 20.2 & 16.3 & 31.0 & 69.0 & 8.5 & 19.9 & 24.3 & 75.7 \\
\hline Manufacture of Automobiles & 13.3 & 15.9 & 24.7 & 75.3 & 6.6 & 18.4 & 23.3 & 76.7 \\
\hline Manufacture of Boats and Ships and Floating Devices & 50.5 & 14.8 & 56.2 & 43.8 & 7.9 & 27.8 & 22.3 & 77.7 \\
\hline Manufacture of Other Transport Equipment & 14.4 & 17.6 & 26.2 & 73.8 & 9.4 & 20.0 & 25.9 & 74.1 \\
\hline Manufacture of Generators & 22.5 & 14.9 & 33.4 & 66.6 & 9.5 & 19.8 & 26.4 & 73.6 \\
\hline $\begin{array}{l}\text { Manufacture of Equipments for Power Transmission and } \\
\text { Distribution and Control }\end{array}$ & 47.6 & 9.3 & 54.9 & 45.1 & 14.2 & 17.4 & 31.1 & 68.9 \\
\hline $\begin{array}{l}\text { Manufacture of Wire, Cable, Optical Cable and Electrical } \\
\text { Appliances }\end{array}$ & 37.1 & 8.3 & 46.6 & 53.4 & 9.1 & 14.7 & 27.6 & 72.4 \\
\hline $\begin{array}{l}\text { Manufacture of Household Electric and Non-electric } \\
\text { Appliances }\end{array}$ & 40.3 & 11.3 & 48.2 & 51.8 & 11.1 & 16.7 & 28.6 & 71.4 \\
\hline Manufacture of Other Electrical Machinery and Equipment & 32.4 & 15.1 & 41.9 & 58.1 & 12.2 & 19.2 & 29.3 & 70.8 \\
\hline Manufacture of Communication Equipment & 50.2 & 14.8 & 56.4 & 43.6 & 27.2 & 15.8 & 44.5 & 55.5 \\
\hline Manufacture of Radar and Broadcasting Equipment & 55.5 & 14.0 & 60.3 & 39.7 & 30.8 & 15.0 & 46.5 & 53.5 \\
\hline Manufacture of Computer & 62.0 & 13.6 & 66.2 & 33.9 & 31.1 & 13.9 & 50.3 & 49.7 \\
\hline Manufacture of Electronic Component & 63.5 & 12.1 & 67.7 & 32.3 & 25.3 & 19.1 & 41.0 & 59.0 \\
\hline Manufacture of Household Audiovisual Apparatus & 64.1 & 12.2 & 67.4 & 32.6 & 30.4 & 17.1 & 46.3 & 53.7 \\
\hline Manufacture of Other Electronic Equipment & 32.3 & 15.7 & 40.7 & 59.3 & 18.1 & 25.7 & 31.7 & 68.3 \\
\hline Manufacture of Measuring Instruments & 50.3 & 18.6 & 55.2 & 44.8 & 17.4 & 25.3 & 32.8 & 67.2 \\
\hline $\begin{array}{l}\text { Manufacture of Machinery for Cultural Activity \& Office } \\
\text { Work }\end{array}$ & 58.8 & 12.4 & 63.5 & 36.5 & 23.6 & 14.4 & 41.6 & 58.4 \\
\hline Manufacture of Artwork, Other Manufacture & 19.2 & 20.4 & 27.7 & 72.3 & 5.4 & 25.0 & 18.0 & 82.0 \\
\hline Scrap and Waste & 10.5 & 74.8 & 11.7 & 88.3 & 3.6 & 80.9 & 5.3 & 94.7 \\
\hline Total Merchandise & 31.6 & 17.1 & 39.4 & 60.6 & 13.7 & 20.3 & 28.7 & 71.3 \\
\hline
\end{tabular}




\section{Appendix Table E Domestic and foreign value-added embodied in Chinese gross merchandise exports, in percent, 2002}

\begin{tabular}{|c|c|c|c|c|c|c|c|c|}
\hline \multirow[b]{2}{*}{ IO industry description } & \multicolumn{4}{|c|}{ Split Method } & \multicolumn{4}{|c|}{ HIY Method } \\
\hline & $\begin{array}{l}\text { Direct } \\
\text { foreign } \\
\text { value- } \\
\text { added } \\
\end{array}$ & $\begin{array}{l}\text { Direct } \\
\text { domestic } \\
\text { value- } \\
\text { added } \\
\end{array}$ & $\begin{array}{l}\text { Total } \\
\text { Foreign } \\
\text { value- } \\
\text { added } \\
\end{array}$ & $\begin{array}{l}\text { Total } \\
\text { Domestic } \\
\text { Value- } \\
\text { added } \\
\end{array}$ & $\begin{array}{l}\text { Direct } \\
\text { foreign } \\
\text { value- } \\
\text { added } \\
\end{array}$ & $\begin{array}{l}\text { Direct } \\
\text { domestic } \\
\text { value- } \\
\text { added } \\
\end{array}$ & $\begin{array}{l}\text { Total } \\
\text { Foreign } \\
\text { value- } \\
\text { added } \\
\end{array}$ & $\begin{array}{l}\text { Total } \\
\text { Domestic } \\
\text { Value- } \\
\text { added }\end{array}$ \\
\hline Agriculture & 2.9 & 64.8 & 6.2 & 93.8 & 1.9 & 65.4 & 6.2 & 93.8 \\
\hline Forestry & 5.0 & 64.5 & 7.8 & 92.3 & 1.8 & 65.5 & 5.4 & 94.6 \\
\hline Logging and transport of timber and bamboo & 5.6 & 60.7 & 8.3 & 91.7 & 2.8 & 60.7 & 7.0 & 93.0 \\
\hline Animal Husbandry & 2.6 & 45.3 & 5.8 & 94.2 & 1.2 & 45.7 & 5.6 & 94.4 \\
\hline Fishery & 2.3 & 54.8 & 6.2 & 93.8 & 1.6 & 55.0 & 6.7 & 93.3 \\
\hline Technical services for agriculture, forestry, livestock and fishing & 24.6 & 47.8 & 26.8 & 73.2 & 2.3 & 54.8 & 7.3 & 92.7 \\
\hline Mining and Washing of Coal & 2.3 & 56.9 & 5.9 & 94.2 & 3.3 & 56.9 & 8.6 & 91.4 \\
\hline Extraction of Petroleum and Natural Gas & 5.0 & 69.5 & 7.5 & 92.5 & 2.9 & 71.1 & 6.6 & 93.4 \\
\hline Ferrous metal ore mining & 8.6 & 46.3 & 12.7 & 87.3 & 5.6 & 46.3 & 11.9 & 88.1 \\
\hline Non-ferrous metal ore mining & 11.9 & 38.5 & 17.7 & 82.3 & 5.0 & 39.9 & 13.8 & 86.2 \\
\hline Salt mining & 5.1 & 63.6 & 7.9 & 92.1 & 2.6 & 63.9 & 7.5 & 92.5 \\
\hline Non-metal minerals and other mining & 20.0 & 37.8 & 24.2 & 75.9 & 4.7 & 44.6 & 12.3 & 87.7 \\
\hline Grain mill products & 50.5 & 13.4 & 52.4 & 47.6 & 3.0 & 20.1 & 8.7 & 91.3 \\
\hline Forage & 19.8 & 16.4 & 23.8 & 76.2 & 5.9 & 18.1 & 12.4 & 87.6 \\
\hline vegetable oil refining & 32.0 & 17.5 & 34.9 & 65.1 & 4.6 & 21.7 & 10.7 & 89.3 \\
\hline Sugar manufacturing & 65.6 & 12.8 & 66.8 & 33.2 & 3.2 & 31.2 & 8.7 & 91.3 \\
\hline Slaughtering and meat processing & 17.5 & 14.6 & 20.6 & 79.4 & 2.2 & 16.1 & 7.9 & 92.1 \\
\hline Fish and fish productions & 12.1 & 20.3 & 16.0 & 84.0 & 2.4 & 24.9 & 8.3 & 91.7 \\
\hline All other food manufacturing & 16.0 & 23.2 & 20.5 & 79.5 & 5.1 & 26.8 & 12.7 & 87.4 \\
\hline Wines, spirits and liquors & 19.7 & 35.7 & 22.9 & 77.1 & 2.8 & 40.7 & 8.6 & 91.4 \\
\hline Soft drink and other beverage & 17.8 & 28.4 & 22.7 & 77.3 & 4.5 & 31.7 & 13.1 & 86.9 \\
\hline Tobacco products & 5.5 & 72.8 & 6.7 & 93.3 & 0.7 & 76.3 & 2.6 & 97.4 \\
\hline Cotton textiles & 18.9 & 20.5 & 24.3 & 75.7 & 8.5 & 23.7 & 18.6 & 81.4 \\
\hline Woolen textiles & 36.4 & 18.4 & 40.0 & 60.1 & 6.3 & 23.5 & 14.9 & 85.1 \\
\hline Hemp textiles & 20.4 & 21.4 & 25.7 & 74.3 & 5.1 & 23.6 & 14.1 & 85.9 \\
\hline Textiles productions & 19.5 & 24.1 & 24.6 & 75.5 & 10.7 & 26.0 & 21.3 & 78.7 \\
\hline Knitted and crocheted fabrics and articles & 22.0 & 26.3 & 27.1 & 72.9 & 10.3 & 27.9 & 21.0 & 79.0 \\
\hline Wearing apparel & 30.1 & 22.1 & 34.4 & 65.6 & 10.5 & 27.1 & 20.9 & 79.2 \\
\hline Leather, fur, down and related products & 32.3 & 15.7 & 36.1 & 63.9 & 13.5 & 20.5 & 23.5 & 76.5 \\
\hline Products of wood, bamboo, cane, palm, straw & 21.7 & 24.8 & 27.2 & 72.8 & 8.2 & 27.8 & 17.3 & 82.7 \\
\hline Furniture & 43.9 & 21.1 & 47.5 & 52.5 & 7.8 & 26.4 & 18.1 & 81.9 \\
\hline Paper and paper products & 46.1 & 21.0 & 48.9 & 51.1 & 7.2 & 29.5 & 15.5 & 84.5 \\
\hline Printing, reproduction of recording media & 67.2 & 23.6 & 68.1 & 31.9 & 5.6 & 42.0 & 13.9 & 86.1 \\
\hline Stationary and related products & 40.2 & 21.8 & 44.2 & 55.8 & 8.4 & 26.9 & 19.6 & 80.4 \\
\hline Toys, sporting and athletic and recreation products & 43.9 & 23.7 & 47.5 & 52.5 & 10.9 & 31.8 & 21.4 & 78.6 \\
\hline Petroleum and nuclear processing & 41.1 & 12.2 & 44.3 & 55.7 & 18.7 & 15.3 & 24.9 & 75.1 \\
\hline Coking & 6.5 & 33.8 & 10.6 & 89.4 & 2.9 & 34.3 & 9.4 & 90.6 \\
\hline Basic chemicals & 12.4 & 27.3 & 18.0 & 82.0 & 9.2 & 28.9 & 17.2 & 82.8 \\
\hline Chemical fertilizers & 12.1 & 22.9 & 18.9 & 81.1 & 7.8 & 23.5 & 18.6 & 81.5 \\
\hline Chemical pesticides & 19.8 & 24.9 & 27.1 & 72.9 & 12.7 & 25.7 & 23.3 & 76.7 \\
\hline paints, varnishes and similar coatings, printing ink and mastics & 32.0 & 18.8 & 38.4 & 61.6 & 10.5 & 22.8 & 22.1 & 77.9 \\
\hline Man-made chemical products & 37.4 & 14.9 & 44.8 & 55.2 & 13.5 & 21.6 & 25.9 & 74.1 \\
\hline Special chemical products & 36.3 & 18.5 & 41.3 & 58.7 & 13.3 & 23.6 & 23.9 & 76.1 \\
\hline Chemical products for daily use & 30.7 & 24.2 & 36.0 & 64.1 & 8.0 & 31.9 & 18.3 & 81.7 \\
\hline Medical and pharmaceutical products & 16.6 & 34.3 & 20.9 & 79.1 & 5.3 & 38.7 & 12.5 & 87.5 \\
\hline Chemical fibers & 26.5 & 19.1 & 34.3 & 65.7 & 13.8 & 21.6 & 26.4 & 73.6 \\
\hline Rubber products & 48.5 & 20.5 & 51.1 & 48.9 & 7.3 & 27.7 & 15.6 & 84.4 \\
\hline Plastic products & 60.0 & 15.9 & 63.4 & 36.6 & 14.6 & 25.1 & 27.9 & 72.1 \\
\hline Cement, lime and plaster & 8.6 & 27.4 & 14.0 & 86.0 & 4.8 & 27.9 & 13.6 & 86.4 \\
\hline
\end{tabular}




\begin{tabular}{|c|c|c|c|c|c|c|c|c|}
\hline \multirow[b]{2}{*}{ IO industry description } & \multicolumn{4}{|c|}{ Split Method } & \multicolumn{4}{|c|}{ HIY Method } \\
\hline & $\begin{array}{l}\text { Direct } \\
\text { foreign } \\
\text { value- } \\
\text { added } \\
\end{array}$ & $\begin{array}{l}\text { Direct } \\
\text { domestic } \\
\text { value- } \\
\text { added }\end{array}$ & $\begin{array}{l}\text { Total } \\
\text { Foreign } \\
\text { value- } \\
\text { added }\end{array}$ & $\begin{array}{l}\text { Total } \\
\text { Domestic } \\
\text { Value- } \\
\text { added }\end{array}$ & $\begin{array}{l}\text { Direct } \\
\text { foreign } \\
\text { value- } \\
\text { added } \\
\end{array}$ & $\begin{array}{l}\text { Direct } \\
\text { domestic } \\
\text { value- } \\
\text { added }\end{array}$ & $\begin{array}{l}\text { Total } \\
\text { Foreign } \\
\text { value- } \\
\text { added } \\
\end{array}$ & $\begin{array}{l}\text { Total } \\
\text { Domestic } \\
\text { Value- } \\
\text { added }\end{array}$ \\
\hline Glass and glass products & 32.3 & 29.5 & 36.4 & 63.6 & 8.4 & 35.2 & 16.8 & 83.2 \\
\hline Pottery, china and earthenware & 14.8 & 30.7 & 20.2 & 79.8 & 5.9 & 32.2 & 14.9 & 85.2 \\
\hline Fireproof materials & 19.9 & 36.5 & 23.8 & 76.2 & 3.8 & 41.4 & 10.9 & 89.1 \\
\hline Other non-metallic mineral products & 15.2 & 31.6 & 19.9 & 80.1 & 4.0 & 33.9 & 12.0 & 88.0 \\
\hline Iron-smelting & 26.8 & 20.3 & 31.2 & 68.8 & 7.0 & 23.2 & 14.2 & 85.8 \\
\hline Steel-smelting & 53.2 & 18.1 & 55.8 & 44.3 & 5.2 & 25.6 & 13.0 & 87.0 \\
\hline Steel pressing & 11.3 & 24.2 & 17.7 & 82.3 & 5.0 & 26.5 & 13.8 & 86.2 \\
\hline Alloy iron smelting & 41.5 & 21.9 & 45.2 & 54.8 & 7.1 & 27.3 & 15.4 & 84.6 \\
\hline Nonferrous metal smelting & 42.6 & 17.1 & 46.4 & 53.6 & 7.4 & 22.0 & 15.9 & 84.1 \\
\hline Nonferrous metal pressing & 46.5 & 12.6 & 50.7 & 49.3 & 9.2 & 16.9 & 20.4 & 79.7 \\
\hline Metal products & 40.3 & 18.5 & 44.3 & 55.7 & 7.0 & 23.7 & 17.1 & 82.9 \\
\hline Boiler, engines and turbine & 28.6 & 25.8 & 33.5 & 66.5 & 9.6 & 30.1 & 19.2 & 80.8 \\
\hline Metalworking machinery & 16.5 & 30.2 & 21.9 & 78.1 & 8.1 & 32.2 & 17.7 & 82.3 \\
\hline Other general industrial machinery & 27.3 & 21.8 & 32.4 & 67.6 & 7.5 & 27.5 & 18.0 & 82.0 \\
\hline Agriculture, forestry, animal husbandry and fishing machinery & 21.4 & 26.2 & 27.1 & 72.9 & 6.7 & 28.8 & 16.9 & 83.1 \\
\hline Other special industrial equipment & 28.9 & 21.9 & 33.6 & 66.4 & 9.3 & 27.4 & 19.2 & 80.8 \\
\hline Railroad transport equipment & 24.5 & 25.7 & 29.9 & 70.1 & 7.4 & 28.4 & 17.5 & 82.5 \\
\hline Motor vehicles & 36.2 & 19.6 & 40.7 & 59.3 & 6.1 & 26.4 & 17.2 & 82.8 \\
\hline Parts and accessories for motor vehicles and their engines & 32.9 & 21.5 & 37.6 & 62.4 & 6.6 & 26.9 & 17.4 & 82.6 \\
\hline Ship building & 82.2 & 15.2 & 82.5 & 17.5 & 12.7 & 23.8 & 23.1 & 77.0 \\
\hline Other transport equipment & 39.7 & 20.5 & 44.2 & 55.8 & 10.9 & 25.0 & 22.3 & 77.7 \\
\hline Generators & 52.4 & 14.4 & 55.7 & 44.3 & 10.5 & 23.5 & 21.4 & 78.6 \\
\hline Household electric appliances & 74.6 & 11.1 & 76.2 & 23.9 & 10.5 & 23.9 & 23.0 & 77.0 \\
\hline Other electric machinery and equipment & 38.8 & 16.4 & 43.9 & 56.2 & 9.9 & 24.4 & 21.8 & 78.2 \\
\hline Telecommunication equipment & 86.8 & 7.3 & 87.5 & 12.5 & 24.2 & 23.5 & 37.9 & 62.1 \\
\hline Electronic computer & 95.3 & 4.0 & 95.4 & 4.6 & 35.2 & 13.2 & 51.5 & 48.5 \\
\hline Other computer peripheral equipment & 75.9 & 7.2 & 77.5 & 22.5 & 35.0 & 20.8 & 46.2 & 53.8 \\
\hline Electronic element and device & 59.2 & 14.7 & 61.9 & 38.1 & 23.4 & 26.1 & 33.3 & 66.7 \\
\hline Radio, television and communication equipment and apparatus & 71.1 & 10.7 & 73.0 & 27.0 & 34.6 & 19.4 & 45.6 & 54.4 \\
\hline Other electronic and communication equipment & 52.3 & 24.6 & 54.7 & 45.3 & 31.7 & 26.0 & 40.2 & 59.8 \\
\hline Instruments, meters and other measuring equipment & 47.6 & 22.4 & 50.5 & 49.5 & 14.6 & 32.1 & 24.3 & 75.7 \\
\hline Cultural and office equipment & 74.8 & 9.1 & 76.7 & 23.3 & 40.0 & 10.6 & 56.8 & 43.2 \\
\hline Arts and crafts products & 33.3 & 20.9 & 37.3 & 62.7 & 7.0 & 27.8 & 16.5 & 83.5 \\
\hline Other manufacturing products & 45.7 & 21.5 & 48.7 & 51.3 & 6.9 & 28.6 & 16.3 & 83.8 \\
\hline Total Merchandise & 42.5 & 19.7 & 46.1 & 53.9 & 15.0 & 26.0 & 25.4 & 74.6 \\
\hline
\end{tabular}

\section{Source: Authors' estimates.}




\section{Appendix Table F Domestic and foreign value-added embodied in Chinese gross merchandise exports, in percent, 1997}

\begin{tabular}{|c|c|c|c|c|c|c|c|c|}
\hline & \multicolumn{4}{|c|}{ Split Method } & \multicolumn{4}{|c|}{ HIY Method } \\
\hline IO industry description & $\begin{array}{l}\text { Direct } \\
\text { foreign } \\
\text { value- } \\
\text { added } \\
\end{array}$ & \begin{tabular}{|l} 
Direct \\
domestic \\
value- \\
added
\end{tabular} & \begin{tabular}{|l} 
Total \\
Foreign \\
value- \\
added \\
\end{tabular} & $\begin{array}{l}\text { Total } \\
\text { Domestic } \\
\text { Value- } \\
\text { added }\end{array}$ & \begin{tabular}{|l|} 
Direct \\
foreign \\
value- \\
added \\
\end{tabular} & \begin{tabular}{|l} 
Direct \\
domestic \\
value- \\
added
\end{tabular} & \begin{tabular}{|l} 
Total \\
Foreign \\
value- \\
added \\
\end{tabular} & $\begin{array}{l}\text { Total } \\
\text { Domestic } \\
\text { Value- } \\
\text { added } \\
\end{array}$ \\
\hline Crop cultivation & 3.5 & 64.4 & 5.4 & 94.6 & 2.5 & 65.0 & 6.0 & 94.0 \\
\hline Forestry & 3.9 & 72.5 & 5.2 & 94.8 & 1.4 & 73.3 & 3.7 & 96.3 \\
\hline Livestock and livestock products & 4.0 & 49.1 & 6.0 & 94.0 & 2.7 & 49.6 & 6.3 & 93.7 \\
\hline Fishery & 6.5 & 58.9 & 8.5 & 91.5 & 2.2 & 60.6 & 6.0 & 94.0 \\
\hline Other agricultural products & 8.0 & 54.9 & 9.6 & 90.4 & 1.8 & 57.2 & 5.3 & 94.7 \\
\hline Coal mining and processing & 1.7 & 51.4 & 4.2 & 95.8 & 3.7 & 51.4 & 9.2 & 90.8 \\
\hline Crude petroleum products & 1.9 & 75.2 & 3.3 & 96.8 & 2.5 & 75.2 & 5.4 & 94.6 \\
\hline Natural gas products & 2.5 & 54.2 & 5.3 & 94.8 & 4.5 & 54.2 & 10.2 & 89.8 \\
\hline Ferrous ore mining & 6.8 & 33.7 & 10.6 & 89.4 & 8.4 & 33.7 & 16.0 & 84.0 \\
\hline Non-ferrous ore mining & 9.1 & 34.9 & 12.3 & 87.8 & 4.4 & 36.1 & 11.5 & 88.5 \\
\hline Salt mining & 3.0 & 59.7 & 5.0 & 95.0 & 2.1 & 60.0 & 7.3 & 92.7 \\
\hline Non-metal minerals and other mining & 19.5 & 35.9 & 22.1 & 77.9 & 4.9 & 40.1 & 11.9 & 88.1 \\
\hline Logging and transport of timber and bamboo & 7.0 & 60.1 & 8.6 & 91.4 & 2.4 & 62.1 & 5.9 & 94.1 \\
\hline Grain mill products, vegetable oil and forage & 48.3 & 12.3 & 49.9 & 50.1 & 3.7 & 18.7 & 9.1 & 90.9 \\
\hline Sugar refining & 80.1 & 11.0 & 80.5 & 19.5 & 3.3 & 18.7 & 9.1 & 90.9 \\
\hline Slaughtering , meat processing, eggs and dairy products & 14.7 & 14.2 & 17.4 & 82.6 & 1.8 & 15.3 & 7.6 & 92.4 \\
\hline Prepared fish and seafood & 12.3 & 19.7 & 14.8 & 85.2 & 1.1 & 25.1 & 6.0 & 94.0 \\
\hline Other food products & 23.5 & 26.5 & 25.7 & 74.3 & 3.8 & 31.3 & 9.7 & 90.3 \\
\hline Wines, spirits and liquors & 17.8 & 29.0 & 20.3 & 79.7 & 3.1 & 32.9 & 9.0 & 91.0 \\
\hline Non-alcoholic beverage & 16.2 & 26.8 & 19.0 & 81.0 & 3.7 & 29.7 & 10.5 & 89.5 \\
\hline Tobacco products & 8.1 & 52.1 & 9.8 & 90.2 & 2.0 & 55.8 & 5.8 & 94.2 \\
\hline Cotton textiles & 35.4 & 23.0 & 37.3 & 62.7 & 8.5 & 28.3 & 18.2 & 81.8 \\
\hline Woolen textiles & 57.8 & 19.0 & 58.7 & 41.3 & 5.8 & 33.5 & 12.3 & 87.7 \\
\hline Hemp textiles & 28.0 & 24.7 & 30.1 & 69.9 & 6.3 & 27.9 & 12.5 & 87.6 \\
\hline Silk textiles & 6.1 & 24.0 & 9.2 & 90.9 & 2.6 & 24.9 & 10.8 & 89.2 \\
\hline Knitted mills & 25.4 & 26.2 & 27.5 & 72.5 & 9.0 & 28.1 & 18.5 & 81.5 \\
\hline Other textiles & 49.0 & 16.8 & 50.4 & 49.6 & 5.7 & 25.9 & 11.6 & 88.4 \\
\hline Wearing apparel & 34.5 & 28.0 & 36.1 & 63.9 & 6.8 & 36.1 & 15.3 & 84.7 \\
\hline Leather, furs, down and related products & 49.5 & 15.7 & 50.9 & 49.2 & 11.6 & 22.6 & 20.6 & 79.4 \\
\hline Sawmills and fiberboard & 21.1 & 26.9 & 23.6 & 76.4 & 6.4 & 30.5 & 13.3 & 86.7 \\
\hline Furniture and products of wood, bamboo, cane, palm, straw, etc. & 38.6 & 20.8 & 40.6 & 59.4 & 7.3 & 26.3 & 16.4 & 83.6 \\
\hline Paper and products & 49.3 & 20.9 & 50.6 & 49.5 & 5.3 & 29.4 & 12.4 & 87.7 \\
\hline Printing and record medium reproduction & 66.2 & 21.1 & 66.8 & 33.2 & 6.3 & 37.4 & 13.6 & 86.4 \\
\hline Cultural goods & 52.8 & 26.0 & 53.9 & 46.1 & 6.4 & 41.1 & 13.7 & 86.3 \\
\hline Toys, sporting and athletic and recreation products & 57.8 & 20.7 & 58.8 & 41.2 & 10.2 & 27.9 & 20.0 & 80.0 \\
\hline Petroleum refining & 50.0 & 14.4 & 51.6 & 48.4 & 15.2 & 22.0 & 20.3 & 79.7 \\
\hline Coking & 5.4 & 22.7 & 8.6 & 91.4 & 2.5 & 23.0 & 9.7 & 90.3 \\
\hline Raw chemical materials & 7.0 & 31.9 & 10.3 & 89.7 & 3.1 & 32.9 & 10.1 & 89.9 \\
\hline Chemical fertilizers & 6.7 & 22.1 & 10.7 & 89.3 & 5.2 & 22.4 & 14.7 & 85.3 \\
\hline Chemical pesticides & 21.7 & 20.4 & 25.4 & 74.6 & 4.9 & 23.0 & 14.6 & 85.4 \\
\hline Organic chemical products & 17.3 & 20.2 & 21.3 & 78.7 & 8.6 & 22.2 & 18.3 & 81.8 \\
\hline Chemical products for daily use & 37.3 & 27.2 & 39.4 & 60.6 & 4.5 & 37.8 & 12.3 & 87.7 \\
\hline Other chemical products & 31.2 & 20.7 & 33.8 & 66.2 & 8.1 & 25.7 & 15.8 & 84.2 \\
\hline Medical and pharmaceutical products & 16.8 & 32.7 & 19.3 & 80.7 & 3.0 & 36.9 & 9.5 & 90.5 \\
\hline Chemical fibers & 61.6 & 14.0 & 63.1 & 36.9 & 14.8 & 23.3 & 25.2 & 74.8 \\
\hline Rubber products & 52.0 & 16.0 & 53.4 & 46.6 & 8.6 & 25.0 & 17.1 & 82.9 \\
\hline Plastic products & 66.8 & 14.6 & 67.9 & 32.1 & 12.9 & 24.3 & 23.6 & 76.4 \\
\hline Cement & 5.2 & 23.6 & 8.8 & 91.2 & 3.9 & 24.0 & 12.7 & 87.3 \\
\hline Cement and asbestos products & 47.6 & 19.0 & 49.4 & 50.7 & 2.4 & 26.8 & 11.1 & 88.9 \\
\hline
\end{tabular}




\begin{tabular}{|c|c|c|c|c|c|c|c|c|}
\hline & \multicolumn{4}{|c|}{ Split Method } & \multicolumn{4}{|c|}{ HIY Method } \\
\hline IO industry description & $\begin{array}{l}\text { Direct } \\
\text { foreign } \\
\text { value- } \\
\text { added } \\
\end{array}$ & \begin{tabular}{|l} 
Direct \\
domestic \\
value- \\
added
\end{tabular} & \begin{tabular}{|l} 
Total \\
Foreign \\
value- \\
added \\
\end{tabular} & \begin{tabular}{|l} 
Total \\
Domestic \\
Value- \\
added
\end{tabular} & \begin{tabular}{|l} 
Direct \\
foreign \\
value- \\
added \\
\end{tabular} & \begin{tabular}{|l} 
Direct \\
domestic \\
value- \\
added
\end{tabular} & \begin{tabular}{|l} 
Total \\
Foreign \\
value- \\
added \\
\end{tabular} & $\begin{array}{l}\text { Total } \\
\text { Domestic } \\
\text { Value- } \\
\text { added } \\
\end{array}$ \\
\hline Bricks, tiles, lime and light-weight building materials & 9.5 & 37.4 & 12.4 & 87.6 & 3.6 & 39.6 & 10.3 & 89.7 \\
\hline Glass and glass products & 37.3 & 24.3 & 39.6 & 60.4 & 4.5 & 30.7 & 12.4 & 87.6 \\
\hline Pottery, china and earthenware & 14.1 & 35.2 & 17.0 & 83.0 & 3.3 & 37.8 & 10.6 & 89.4 \\
\hline Fireproof products & 9.3 & 27.3 & 12.7 & 87.3 & 3.6 & 28.5 & 11.6 & 88.4 \\
\hline Other non-metallic mineral products & 18.7 & 27.5 & 21.8 & 78.2 & 3.0 & 30.9 & 10.6 & 89.4 \\
\hline Iron-smelting & 79.8 & 13.8 & 80.1 & 19.9 & 5.7 & 22.3 & 12.9 & 87.1 \\
\hline Steel-smelting & 67.3 & 16.8 & 68.2 & 31.8 & 3.9 & 23.7 & 11.6 & 88.4 \\
\hline Steel processing & 61.2 & 12.3 & 62.8 & 37.3 & 5.9 & 21.0 & 15.1 & 84.9 \\
\hline Alloy iron smelting & 43.6 & 17.0 & 46.1 & 53.9 & 5.5 & 21.4 & 14.2 & 85.8 \\
\hline Nonferrous metal smelting & 35.5 & 15.8 & 38.1 & 62.0 & 4.6 & 19.5 & 12.5 & 87.6 \\
\hline Nonferrous metal processing & 34.0 & 11.7 & 37.2 & 62.8 & 7.2 & 15.4 & 16.7 & 83.3 \\
\hline Metal products & 31.5 & 18.6 & 34.3 & 65.7 & 5.9 & 23.3 & 15.4 & 84.6 \\
\hline Boiler, engines and turbine & 29.9 & 28.3 & 32.6 & 67.4 & 7.4 & 34.6 & 15.5 & 84.5 \\
\hline Metalworking machinery & 22.1 & 28.2 & 25.1 & 74.9 & 5.8 & 31.9 & 14.5 & 85.5 \\
\hline Other general industrial machinery & 36.9 & 27.9 & 39.0 & 61.0 & 5.3 & 37.7 & 13.3 & 86.8 \\
\hline Agriculture, forestry, animal husbandry and fishing machinery & 10.1 & 21.0 & 14.6 & 85.4 & 6.5 & 21.8 & 17.2 & 82.8 \\
\hline Other special industrial equipment & 36.1 & 25.0 & 38.4 & 61.6 & 7.6 & 32.5 & 16.3 & 83.7 \\
\hline Railroad transport equipment & 43.1 & 21.5 & 45.6 & 54.4 & 5.5 & 26.3 & 15.2 & 84.8 \\
\hline Motor vehicles & 35.5 & 19.5 & 38.1 & 61.9 & 5.2 & 25.7 & 15.3 & 84.7 \\
\hline Ship building & 78.7 & 15.6 & 79.1 & 21.0 & 8.1 & 28.7 & 17.6 & 82.4 \\
\hline Aircraft & 33.3 & 38.8 & 35.3 & 64.7 & 23.5 & 42.4 & 28.0 & 72.0 \\
\hline Bicycle & 73.8 & 11.5 & 74.8 & 25.2 & 6.5 & 18.8 & 18.0 & 82.0 \\
\hline Other transport machinery & 38.5 & 20.3 & 41.2 & 58.9 & 6.2 & 27.4 & 16.3 & 83.7 \\
\hline Generators & 73.6 & 14.2 & 74.3 & 25.7 & 7.9 & 26.2 & 17.8 & 82.2 \\
\hline Household electric appliances & 74.1 & 12.8 & 74.9 & 25.1 & 8.7 & 26.3 & 19.7 & 80.3 \\
\hline Other electric machinery and equipment & 69.7 & 12.4 & 70.9 & 29.2 & 9.0 & 19.7 & 20.0 & 80.0 \\
\hline Electronic computer & 83.5 & 9.2 & 83.9 & 16.1 & 24.5 & 23.4 & 36.7 & 63.3 \\
\hline Electronic appliances & 80.9 & 9.1 & 81.5 & 18.5 & 21.5 & 19.8 & 33.5 & 66.5 \\
\hline Electronic element and device & 66.3 & 15.1 & 67.3 & 32.7 & 14.6 & 29.7 & 23.6 & 76.4 \\
\hline Other electronic and communication equipment & 82.0 & 13.1 & 82.3 & 17.7 & 18.3 & 27.3 & 30.0 & 70.0 \\
\hline Instruments, meters and other measuring equipment & 61.0 & 22.6 & 61.8 & 38.2 & 10.6 & 36.3 & 19.1 & 80.9 \\
\hline Cultural and office equipment & 84.5 & 8.5 & 84.9 & 15.2 & 15.6 & 19.8 & 26.9 & 73.1 \\
\hline Arts and crafts products & 42.1 & 21.0 & 43.9 & 56.1 & 6.1 & 29.8 & 14.2 & 85.9 \\
\hline Other manufacturing products & 61.2 & 21.0 & 62.1 & 37.9 & 5.5 & 34.3 & 13.7 & 86.3 \\
\hline Total Merchandise & 44.4 & 22.2 & 46.0 & 54.0 & 9.0 & 29.4 & 17.9 & 82.1 \\
\hline
\end{tabular}

Source: Authors’ estimates. 